\title{
Working
}

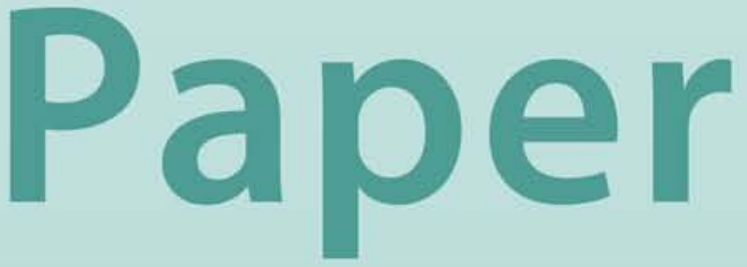




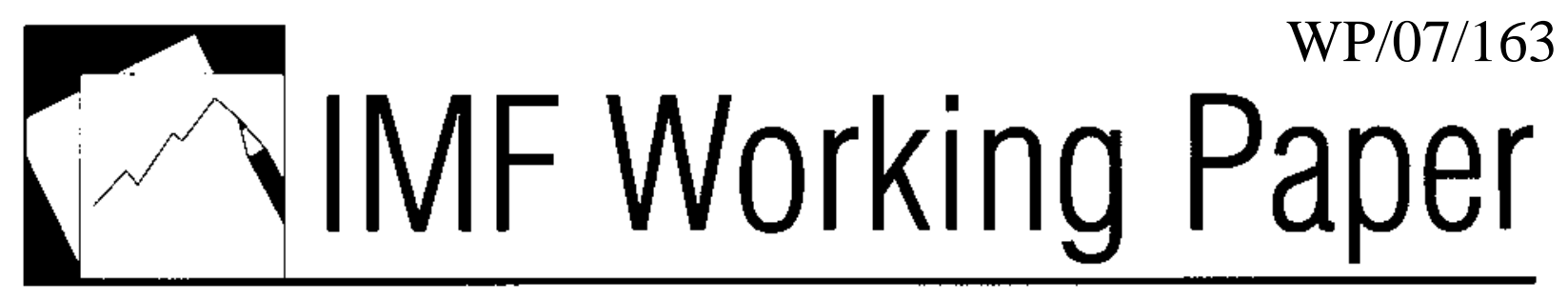

\section{The Role of Nonseparable Utility and Nontradeables in International Business Cycles and Portfolio Choice}

Akito Matsumoto 


\title{
IMF Working Paper
}

\author{
Research Department
}

\section{The Role of Nonseparable Utility and Nontradeables in International Business Cycles and Portfolio Choice}

\author{
Prepared by Akito Matsumoto ${ }^{1}$
}

Authorized for distribution by Stijn Claessens

July 2007

\begin{abstract}
This Working Paper should not be reported as representing the views of the IMF.

The views expressed in this Working Paper are those of the author(s) and do not necessarily represent those of the IMF or IMF policy. Working Papers describe research in progress by the author(s) and are published to elicit comments and to further debate.

This paper analyzes the role of nonseparable utility and nontradables in business cycles and portfolio choice. I find that nonseparability in utility can change the portfolio choice significantly. Unlike previous results in literature, the optimal portfolio of the traded-good sector equities is no longer a well diversified portfolio and becomes sensitive to parameter values. As a result, the model often generates extreme home bias or anti-home bias portfolios implying that some frictions in asset markets, which prevent agents from holding these extreme portfolios, can explain the lack of international risk sharing.

JEL Classification Numbers: E32, F30, F40, G11

Keywords: international business cycle; international portfolio choice; nonseparability in utility; nontraded goods; nontraded factors

Author’s E-Mail Address: amatsumoto@imf.org

\footnotetext{
${ }^{1}$ I thank Mick Devereux, Charles Engel, Fabio Ghironi, Urban Jermann, Karen Lewis, Enrique Mendoza, Eric van Wincoop, Randy Wright, participants at the NBER IFM meeting, and my IMF colleagues, especially Anna Ivanova and Julian di Giovanni, for comments and suggestions. The views expressed in this paper are those of the author and should not be attributed to the International Monetary Fund, its Executive Board, or its management. All errors are my own.
} 


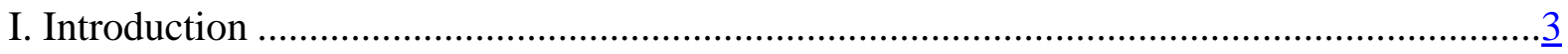

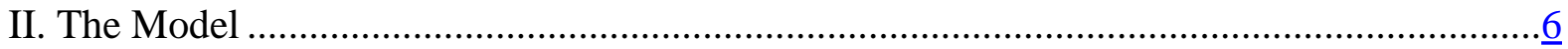

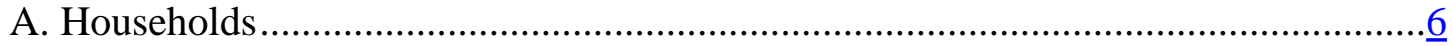

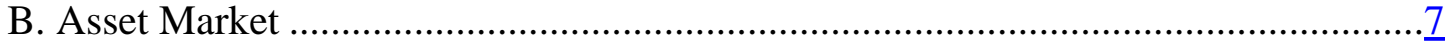

C. First Order Conditions............................................................................... $\frac{8}{8}$

D. Firms and Technology .............................................................................

E. Market Clearing Conditions .............................................................................

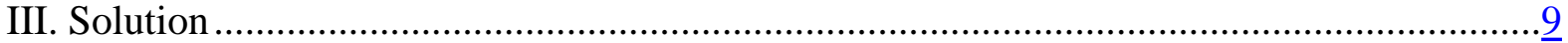

A. Solution for the Complete Asset Market Allocation ….........................................

IV. The Optimal Portfolio ..........................................................................................

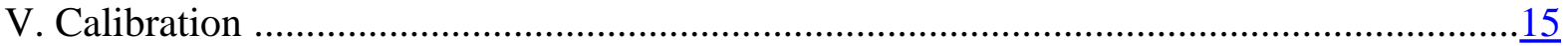

A. The Choice of Parameter Values ............................................................. $\frac{15}{16}$

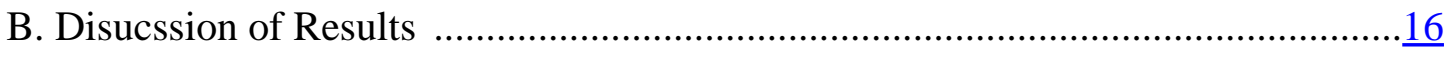

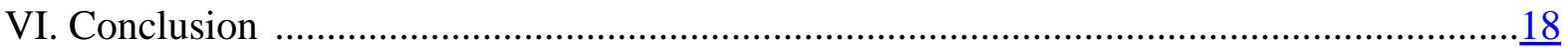

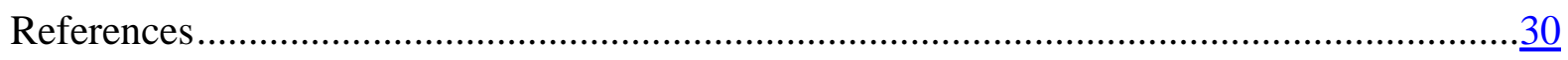

Tables

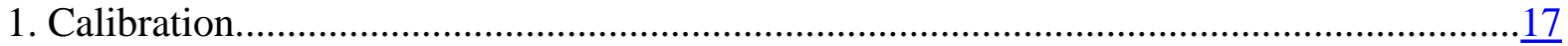

2. List of Parameters and Benchmark Values .............................................................

Figures

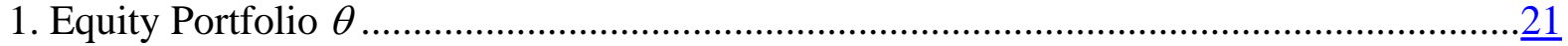

2. Equity Portfolio $\mu$............................................................................................... 22

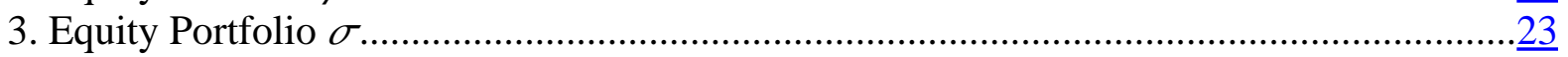

Appendixes

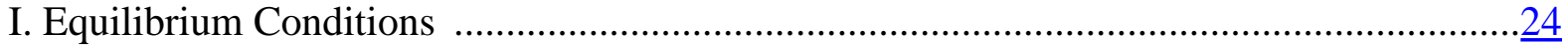

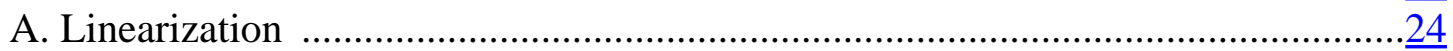

B. Solution: World Variables.......................................................................... $\frac{25}{26}$

C. Solution: Relative Variables......................................................................

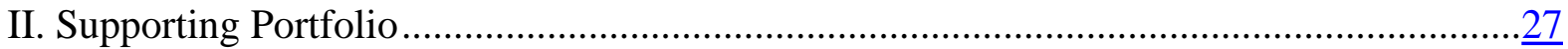

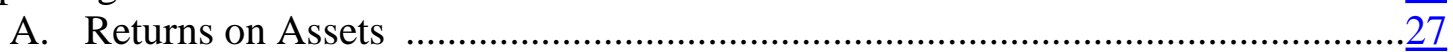

1. Return on Human Capital ......................................................................27

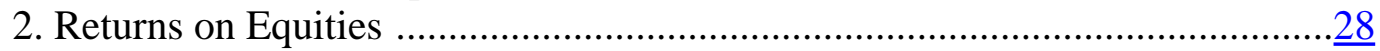

3. Solution: Portfolio Allocation …............................................................. 28 


\section{INTRODUCTION}

Both nontraded factors and nontraded goods are important elements in explaining balance of payment adjustments, real exchange rates, capital flows, portfolio allocation, and many other phenomena. ${ }^{2}$ However, nontraded goods and nontraded factors are often abstracted from an open economy model due to technical difficulties. For this reason, the transmission mechanism of productivity shocks in a model with nontraded goods and nontraded factors has not been studied extensively. In some papers, a numerical solution is used to answer specific questions of interest, but this solution method often makes it difficult to uncover the underlying mechanism. As a result, the optimal portfolio to insure country-specific productivity shocks has not been investigated as much either. This is the first paper to solve the optimal portfolio choice problem with both nontraded goods and nontraded factors in a general equilibrium setting.

The contribution of this paper is twofold. The primary contribution is a closed form solution for the optimal portfolio, which sheds new light on international risk sharing. The optimal portfolio in this model tends to be too extreme to hold in a realistic world, suggesting that incomplete international risk sharing is likely due to asset market frictions instead of missing assets. ${ }^{3}$ The secondary contribution is a new insight about international business cycle models with nontraded goods and nontraded factors that arises from solving a model analytically. Although the model does not incorporate other important features such as sticky prices and investment, it nests a few important previous models of international portfolio allocation. As my model generalizes the past results, it serves as a stepping stone to more sophisticated models, which may not have a closed form solution.

The role of nontraded goods has been studied to explain deviation from purchasing power parity, low cross-country consumption correlation, ${ }^{4}$ home bias, and other puzzles. ${ }^{5}$ Backus and Smith (1993) build a two-country endowment economy model with nontraded goods, which can explain some of these puzzles in principle. However, the model introduces another puzzle; namely, a perfect correlation between relative consumption across countries and real exchange rates, which is not observed in the data. Stockman and Tesar (1995) build a two-country production model with nontraded goods and investment to replicate many features of both cross-country and within-country correlations. They succeed in matching the saving-investment correlation, the trade balance-output correlation, and the consumption-output correlation by introducing taste shocks. However, their model overpredicts the cross-country consumption correlation like other international real business cycle models. ${ }^{6}$ My model setup is close to that of Stockman and Tesar, which features imperfect

\footnotetext{
${ }^{2}$ For example, Obstfeld and Rogoff (2005a, 2005b) emphasize the role of nontraded goods in current account adjustments. Evans and Hnatkovska (2005) study capital flows under different asset market settings with nontraded goods. Burstein, Neves and Rebelo (2003), Burstein, Eichenbaum and Rebelo (2005, 2006), Benigno and Toenissen (2006), and Corsetti, Dedola and Leduc (2006) try to explain real exchange rate behavior by including nontraded goods. All of them use numerical solution.

${ }^{3}$ I do not claim that I provide a potential solution for the home bias puzzle in this paper.

${ }^{4}$ Backus, Kehoe and Kydland (1992) build international business cycle model which predicts near unity cross-country consumption correlation but find that consumption correlation is lower than output correlation in the data.

${ }^{5}$ See Lewis (1995) and Lewis (1999) for various puzzles.

${ }^{6}$ Devereux, Gregory and Smith (1992) utilize nonseparable utility to explain cross-country consumption with a single good model. Tesar (1993) adopt a production economy to explain these puzzles in her model with a single good. For small open economy, see Engel and Kletzer (1989) and Balsam and Eckstein (2001).
} 
substitution between home traded goods and foreign traded goods, nonseparable utility between consumption and leisure, and complete asset markets.

I focus on the general form of the utility function because Lewis (1996) finds that nonseparability and certain asset market frictions may be necessary to explain international consumption risk sharing. ${ }^{7}$ Unlike Stockman and Tesar and others, I abstract from investment in order to solve for allocation in a closed form. While the lack of investment goods is an obvious shortcoming of my model, it allows me to solve analytically for the optimal allocation as a linear function of productivity shocks. ${ }^{8}$ This solution in turn sheds light on the cross-country transmission mechanism of productivity shocks. ${ }^{9}$ However, I find that nonseparability does not alter the business cycle behavior of the model enough to explain existing puzzles though it certainly changes many moments significantly.

The role of nontraded goods in portfolio allocation has not been studied in great detail either. Stockman and Dellas (1989) made an earlier contribution to solve for the optimal portfolio with nontraded goods. They study an endowment economy with separable utility between nontraded and traded goods. Their optimal equity portfolio is a combination of a well diversified portfolio in traded good sector equities and a complete home bias portfolio in nontraded good sector equities. ${ }^{10}$ One of the most important theoretical works on this issue is Baxter, Jermann and King (1998). They study portfolio allocation in an endowment economy, and find that the optimal portfolio of traded good sector equities is a diversified world portfolio, while optimal holdings of nontraded good sector equities can exhibit either home bias or anti-home bias depending on the elasticity of substitution between traded and nontraded goods. They also incorporate nontraded factors by introducing human capital whose returns are perfectly correlated with returns to domestic physical capital without including leisure in the utility. They concluded that the presence of nontraded goods cannot explain home bias because the optimal portfolio of traded good sector equities is well diversified in their model. ${ }^{11}$

The role of nontraded factors has received slightly more attention in the literature. ${ }^{12}$ Jermann (2002) incorporates endogenous labor supply into international portfolio allocation but abstracts from the nontraded good sector. Nevertheless, he finds that if the utility function exhibits nonseparability

\footnotetext{
${ }^{7}$ However, Lewis also finds that nonseparability alone is not enough to explain the lack of risk sharing

${ }^{8}$ Heathcote and Perriy (2004) assume Cobb-Douglas aggregation but include capital accumulation.

${ }^{9}$ For example, the potential reason Stockman and Tesar (1995) fails to generate country specific variation in consumption of traded goods is their Cobb-Douglas aggregation of home traded goods and foreign traded goods.

${ }^{10}$ Tesar (1993) has also discussed equity portfolio but the portfolio is suboptimal.

${ }^{11}$ Another important work in this area is Kollmann (2006a), who corrects the solution of portfolio choice problem with nontraded goods by Serrat (2001). Kollmann shows that the optimal portfolio of traded goods equities is still well diversified under Serrat's assumption. Pesenti and van Wincoop (2002) also study optimal portfolio choice with nontraded goods in a partial equilibrium model. Hnatkovska (2005) studies asset allocation under incomplete market setup. Home bias in consumption is also related. Heathcote and Perriy (2004) use simple utility but included capital accumulation. Kollmann (2006b) studies the effects of home bias in consumption on portfolio. On the other hand, van Wincoop and Warnock (2006) find that home bias in consumption does not help explain home bias in portfolio in a partial equilibrium setup. The recent studies on international portfolio includes Evans and Hnatkovska (2005, 2006, 2007), Devereux and Sutherland(2006, 2007a, 2007b), Ghironi, Lee and Rebucci (2007), Tille and van Wincoop (2007).
}

\footnotetext{
${ }^{12}$ Using a simple model, Baxter and Jermann (1997) predicts that international diversification puzzle is worse than we think. On the other hand, Bottazzi, Pesenti and van Wincoop (1996) and Julliard (2002) find that labor income can help explain home bias in the data.
} 
between consumption and leisure, then the optimal portfolio can differ substantially from a well diversified portfolio. In addition, Engel and Matsumoto (2006) show that home bias may be optimal to hedge labor income risk in a sticky price model. They find that the elasticity of substitution between home traded goods and foreign traded goods plays an important role in portfolio allocation. These studies suggest that a general utility function and nontradables are important in explaining home bias.

While it is important to incorporate a general utility function in a model, it has to be simple enough to allow for an analytical solution. In order to establish a benchmark case and to solve a model analytically, I assume complete asset markets. While this assumption may be relaxed in the future, without understanding complete market settings, it is difficult to judge which form of incompleteness is more appropriate.

In my model, agents have nonseparable utility between leisure and consumption. The consumption basket is a CES aggregate of traded and nontraded goods, and the traded good basket is also a CES aggregate of home and foreign traded goods. I solve for the optimal international portfolio allocation as a function of model parameters in order to analyze the determinants of portfolio allocation. I find that the elasticity of substitution between home and foreign traded goods (the Armington elasticity) does not enter this function unless it is unity. In case of unity, the portfolio weight for traded good sector equities is indeterminant. This indeterminacy may be eliminated when one introduces sticky prices as presented in Engel and Matsumoto (2006), who show that a slight degree of price stickiness can generate home bias if the elasticity is unity.

Most important, the optimal portfolio of traded good sector equities is no longer a well diversified world portfolio unlike the results of Stockman and Dellas (1989) or Baxter et al. (1998) once nonseparability is introduced. So we have to ask the same question again, 'Can the presence of nontraded consumption goods or nontraded factors of production explain a high degree of "home bias" displayed by investor portfolios?' The answer is 'it depends' on the model parameters once we assume nonseparability.

Empirical supports for nontraded goods as explanation to home bias in equity are generally weak while those for nontraded factors are relatively favorable. Pesenti and van Wincoop (2002) and van Wincoop and Warnock (2006) find that nontraded goods or home bias in consumption cannot explain home bias in equity. On the other hand, Bottazzi et al. (1996), Palacios-Huerta (2001), and Julliard (2002) find that human capital may explain home bias to certain degree. Also, Lustig and Nieuwerburgh (2006) find that innovations in human capital returns are negatively correlated with innovations in financial asset returns.

The characteristics of portfolios of both nontraded and traded good sector equities in my model look similar to the portfolio of nontraded good sector equities in Baxter et al. (1998). That is, the optimal equity portfolios of both sectors are sensitive to the elasticity of substitution between traded and nontraded goods. In addition, the optimal portfolios in my model are sensitive to the coefficient of relative risk aversion and the elasticity of substitution between leisure and consumption. The optimal share of foreign equities can take any value from negative infinity to positive infinity depending on the model parameters. This in turn suggests that the introduction of some frictions in asset markets such as short-selling constraints, which prevents agents from taking these extreme asset positions, can explain the lack of international risk sharing even if the asset market structure is complete. This theoretical implication is in line with the empirical results in Lewis (1996), who cannot reject the null hypothesis of complete markets with capital market frictions and nonseparability in utility. 
I explain the model setup briefly in the next section. Then, I solve for real allocations and prices in section 3 and for portfolio allocation in section 4 . I discuss calibration in section 5 and conclude in section 6 .

\section{THE MODEL}

The model is a completely-technology-shock-driven two-country, two-sector production stochastic general equilibrium model. Prices are assumed to be flexible. Given this, the model features a standard international real business cycle model setup with nontraded goods except for endogenous portfolio choice. Since the model replicates the complete market allocation in a linearized solution, it has similar business cycle properties to those of Stockman and Tesar (1995) or Tesar (1993). However, I abstract from investment but introduce the utility function and the aggregation of traded goods in a more general way. By doing so, I incorporate the insights from both Lewis (1996), who finds nonseparability in utility function is one of the important elements to explain international consumption risk sharing, and Jermann (2002), who finds that nonseparability can potentially explain home bias in equities.

\section{A. Households}

There are two countries, Home and Foreign, with populations " $n$ " and " $1-n$," respectively. Except for the difference in size, they have symmetric preferences and identical technology. The representative household $j$ in Home country solves

$$
\max _{\vec{\gamma}_{t}(j), \cdots} E_{t-1} \max _{C_{t}(j), L_{t}(j), \cdots} \sum_{s=t}^{\infty} U\left(C_{s}(j), L_{s}(j)\right), \quad \text { s.t. budget constraint, }
$$

where $U$ is a well-defined utility function with $U_{C}>0$, and $U_{L}<0 . C_{t}(j)$ denotes the consumption basket of Home agent $j$, and $L_{t}(j)$, the labor supply. I define the utility function quite generally because nonseparability is an important feature explaining risk sharing and asset allocation as emphasized in Lewis (1996) and Jermann (2002).

$C_{t}(j)$ is a consumption basket of a representative Home household defined as

$$
\begin{aligned}
C_{t}(j) & \equiv\left[\eta^{1 / \theta} C_{N, t}(j)^{(\theta-1) / \theta}+(1-\eta)^{1 / \theta} C_{T, t}(i)^{(\theta-1) / \theta}\right]^{\theta /(\theta-1)} \\
C_{T, t}(j) & \equiv\left[n^{1 / \omega} C_{h, t}(j)^{(\omega-1) / \omega}+(1-n)^{1 / \omega} C_{f, t}(j)^{(\omega-1) / \omega}\right]^{\omega /(\omega-1)},
\end{aligned}
$$

where $\theta>0$ is the elasticity of substitution between traded and nontraded goods and $\omega>0$ is the elasticity of substitution between Home and Foreign produced traded goods. I assume an identical utility function for Foreign households to avoid home bias in traded goods consumption. As I will show later, it is also important to have general CES aggregation instead of Cobb-Douglas aggregation in order to examine asset allocation and the transmission mechanism. $C_{h, t}$ is the consumption basket 
of Home produced traded goods and $C_{f, t}$ is that of Foreign produced traded goods defined as follows:

$$
\begin{aligned}
C_{h, t}(j) & \equiv\left[n^{-1 / \lambda} \int_{0}^{n} C_{h, t}(j, i)^{(\lambda-1) / \lambda} d i\right]^{\lambda /(\lambda-1)}, \\
C_{f, t}(j) & \equiv\left[(1-n)^{-1 / \lambda} \int_{n}^{1}, C_{f, t}(j, i)^{(\lambda-1) / \lambda} d i\right]^{\lambda /(\lambda-1)}, \\
C_{N, t}(j) & \equiv\left[\int_{0}^{1} C_{N, t}(j, i)^{(\lambda-1) / \lambda} d i\right]^{\lambda /(\lambda-1)},
\end{aligned}
$$

where $\lambda$ denotes the elasticity of substitution among varieties, with $\lambda>1 .{ }^{13}$ The CPI can be written as

$$
P_{t}=\left(\eta \tilde{P}_{N, t}^{1-\theta}+(1-\eta) \tilde{P}_{T, t}^{1-\theta}\right)^{1 /(1-\theta)}
$$

where

$$
\begin{array}{ll}
\tilde{P}_{T, t}=\left[n \tilde{P}_{h, t}^{1-\omega}+(1-n) \tilde{P}_{f, t}^{1-\omega}\right]^{1 /(1-\omega)}, & \tilde{P}_{N, t}=\left[\int_{0}^{1} \tilde{P}_{N, t}(i)^{1-\lambda} d i\right]^{1 /(1-\lambda)}, \\
\tilde{P}_{h, t}=\left[1 / n \int_{0}^{n} \tilde{P}_{h, t}(i)^{1-\lambda} d i\right]^{1 /(1-\lambda)}, & \tilde{P}_{f, t}=\left[1 /(1-n) \int_{n}^{1} \tilde{P}_{f, t}(i)^{1-\lambda} d i\right]^{1 /(1-\lambda)},
\end{array}
$$

where $\tilde{P}_{N, t}(i)$ is the nominal price of Home nontraded good, $\tilde{P}_{h, t}(i)$ is the price of Home traded good $i$ sold in Home, and $\tilde{P}_{f, t}(i)$ is the price of Foreign traded good $i$ sold in Home. I use asterisks to denote foreign prices and quantities.

Let $S_{t}$ be the Home currency price of Foreign currency. Then the real exchange rate is

$$
Q_{t} \equiv \frac{S_{t} P_{t}^{*}}{P_{t}}
$$

Since all prices are flexible in this model, nominal prices and the nominal exchange rate are indeterminant, but relative prices can be determined. I denote relative prices to CPI in each country as

$$
Z_{t} \equiv \frac{\tilde{Z}_{t}}{P_{t}}, \quad Z_{t}^{*} \equiv \frac{\tilde{Z}_{t}^{*}}{P_{t}^{*}},
$$

for any nominal values, $Z_{t}$, including wages, equity prices and firms' profits.

\section{B. Asset Market}

I assume that agents can choose holdings of 4 mutual funds, which pay the profit of Home or Foreign firms in the traded or nontraded good sectors. Households choose portfolios paying dividends at time $t$ before the realization of time $t$ shocks.

\footnotetext{
${ }^{13}$ I use monopolistic competition in this model, which is equivalent to having firms with fixed capital and a Cobb-Douglas production function.
} 
Let $\tilde{X}_{., h, t}$ denote the ex-dividend equity price of a Home firm in Home currency. Let $\gamma_{., h, t}(j)$ denote the number of shares owned by individual $j$ of Home firms producing traded or nontraded goods. Let $\overrightarrow{\gamma_{t}} \equiv\left(\gamma_{T, h, t}, \gamma_{T, f, t}, \gamma_{N, h, t}, \gamma_{N, f, t}\right)^{\prime}$, and $\overrightarrow{\tilde{\Pi}}_{t}$ be defined analogously where $\tilde{\Pi}_{T, h, t}$ is the nominal profit (dividend) of Home firms producing traded goods. Therefore, the budget constraint of Home household $j$ in real terms can be written as

$$
C_{t}(j)+\overrightarrow{\gamma_{t+1}(j)^{\prime}} \vec{X}_{t}=W_{t}(j) L_{t}(j)+\overrightarrow{\gamma_{t}(j)^{\prime}}\left(\vec{X}_{t}+\vec{\Pi}_{t}\right)
$$

\section{First Order Conditions}

Since households are identical in each country, I will suppress household index $j$ from now on. Given prices and the total consumption basket $C_{t}$, the optimal consumption allocations are

$$
\begin{aligned}
C_{N, t} & =\eta\left(P_{N, t}\right)^{-\theta} C_{t}, & C_{T, t} & =(1-\eta)\left(P_{T, t}\right)^{-\theta} C_{t}, \\
C_{f, t} & =n\left(\frac{P_{h, t}}{P_{T, t}}\right)^{-\omega} C_{T, t}, & C_{f, t} & =(1-n)\left(\frac{P_{f, t}}{P_{T, t}}\right)^{-\omega} C_{T, t}, \\
C_{h, t}(i) & =\frac{1}{n}\left(\frac{P_{h, t}(i)}{P_{h, t}}\right)^{-\lambda} C_{h, t}, & C_{f, t}(i) & =\frac{1}{1-n}\left(\frac{P_{f, t}(i)}{P_{f, t}}\right)^{-\lambda} C_{f, t}, \\
C_{N, t}(i) & =\left(\frac{P_{N, t}(i)}{P_{N, t}}\right)^{-\lambda} C_{N, t} . & &
\end{aligned}
$$

Labor supply conditions, and Euler equations are also standard:

$$
\begin{aligned}
W_{t} & =-\frac{U_{L}\left(C_{t}, L_{t}\right)}{U_{C}\left(C_{t}, L_{t}\right)} \\
X_{., ., t} & =E_{t}\left[\frac{\beta U_{C}\left(C_{t+1}, L_{t+1}\right)}{U_{C}\left(C_{t}, L_{t}\right)}\left(X_{.,, t+1}+\Pi_{.,, t+1}\right)\right] .
\end{aligned}
$$

\section{Firms and Technology}

The production functions for firms producing traded and nontraded good are respectively

$$
Y_{T, t}(i)=A_{T, t} L_{T, t}(i), \quad Y_{N, t}(i)=A_{N, t} L_{N, t}(i),
$$

where $A_{., t}$ is technology level in each sector, and $L_{., t}$ is labor hours used in each firm. Technology is assumed to be sector specific. I assume that labor is mobile between the two sectors within a country. Therefore, the wage rate will be the same across the two sectors. I assume that the logarithm of technology level in each sector and each country follows an i.i.d. process.

Firms set prices in each period to maximize profits after the realization of shocks:

$$
P_{., ., t}(i)=\frac{\lambda}{\lambda-1} \frac{W_{t}}{A_{., t}} .
$$


Because firms in each sector are identical, I omit index $i$. Home firms' profits in each period are simply:

$$
\Pi_{.,, t}=P_{.,, t} Y_{., ., t}-W_{.,, t} L_{., ., t}=\frac{1}{\lambda-1} W_{t} L_{., ., t}
$$

\section{E. Market Clearing Conditions}

The goods market clearing conditions are

$$
n A_{T, t} L_{T, t}=n C_{h, t}+(1-n) C_{h, t}^{*}, \quad n A_{N, t} L_{N, T}=n C_{N, t} .
$$

The labor market clearing condition is

$$
L_{t}=L_{N, t}+L_{T, t},
$$

where $L_{N, t}=\int_{0}^{1} L_{N, t}(i) d i$, and $L_{T, t}=\int_{0}^{n} L_{T, t}(i) d i$. Asset market clearing conditions are

$$
\begin{array}{ll}
n \gamma_{T, h, t}+(1-n) \gamma_{T, h, t}^{*}=n, & n \gamma_{T, f, t}+(1-n) \gamma_{T, f, t}^{*}=1-n, \\
n \gamma_{N, h, t}+(1-n) \gamma_{N, h, t}^{*}=1, & n \gamma_{N, f, t}+(1-n) \gamma_{N, f, t}^{*}=1 .
\end{array}
$$

\section{Solution}

I first solve for the real allocation that replicates the complete asset market allocation and then find the supporting portfolio for this allocation in the following section. The complete market assumption implies

$$
Q_{t}=\frac{S_{t} P_{t}^{*}}{P_{t}}=\kappa \frac{U_{C}\left(C_{t}^{*}, L_{t}^{*}\right)}{U_{C}\left(C_{t}, L_{t}\right)} .
$$

While $\kappa$ is a part of the solution, which depends on initial conditions, it is not important for asset allocation; therefore, I assume $\kappa=1$ for simplicity. ${ }^{14}$ In the initial period, $t=0$, I assume $A_{N, t}=A_{T, t}=A_{N, t}^{*}=A_{T, t}^{*}=1$. I use log approximation to solve for an equilibrium.

\section{A. Solution for the Complete Asset Market Allocation}

This subsection discusses key aspects of the solution. Details are in the separate Appendix. Lower-case letters refer to log deviations from the initial state. World variables are defined as $x_{t}^{W} \equiv n x_{t}+(1-n) x_{t}^{*}$ and relative variables as $x_{t}^{R} \equiv x_{t}-x_{t}^{*}$. This in turn means that $x_{t}=x_{t}^{W}+(1-n) x_{t}^{R}$. For example, the total consumption in Home is $c_{t}=c_{t}^{W}+(1-n) c_{t}^{R}$, and $c_{t}^{R}$ can be regarded as the country specific component.

\footnotetext{
${ }^{14}$ This is equivalent to setting arbitrary weights for Home and Foreign in the social welfare function. This equilibrium can be supported by the wealth transfer in the initial period.
} 
Let $\psi=\frac{U_{L L}(\bar{C}, \bar{L}) \bar{L}}{U_{L}(\bar{C}, \bar{L})}, \phi_{C}=-\frac{U_{C L}(\bar{C}, \bar{L}) \bar{L}}{U_{C}(\bar{C}, \bar{L})}, \phi_{L}=\frac{U_{C L}(\bar{C}, \bar{L}) \bar{C}}{U_{L}(\bar{C}, \bar{L})}$, and $\rho=-\frac{U_{C C}(\bar{C}, \bar{L}) \bar{C}}{U_{C}(\bar{C}, \bar{L})}$, where $\bar{X}$ is the initial symmetric state value of $X$, and $U_{X Y}=\frac{\partial^{2} U}{\partial X \partial Y}$. For example, ${ }^{15}$ if

$$
U(C, L)=\frac{1}{1-\sigma}\left[\gamma^{\frac{1}{\mu}} C^{\frac{\mu-1}{\mu}}+(1-\gamma)^{\frac{1}{\mu}}(1-L)^{\frac{\mu-1}{\mu}}\right]^{\frac{\mu(1-\sigma)}{\mu-1}} .
$$

Then,

$$
\begin{aligned}
\rho & =\frac{1}{\mu}-s_{c}\left(\frac{1}{\mu}-\sigma\right), & \phi_{C} & =\left(1-s_{c}\right)\left(\frac{1}{\mu}-\sigma\right) \frac{\bar{L}}{1-\bar{L}}, \\
\phi_{L} & =s_{c}\left(\frac{1}{\mu}-\sigma\right), & \psi & =\left[\frac{1}{\mu}-\left(1-s_{c}\right)\left(\frac{1}{\mu}-\sigma\right)\right] \frac{\bar{L}}{1-\bar{L}},
\end{aligned}
$$

where

$$
s_{c}=\frac{\gamma^{\frac{1}{\mu}} \bar{C}^{\frac{\mu-1}{\mu}}}{\gamma^{\frac{1}{\mu}} \bar{C}^{\frac{\mu-1}{\mu}}+(1-\gamma)^{\frac{1}{\mu}}(1-\bar{L})^{\frac{\mu-1}{\mu}}} .
$$

The following set of equations describes key relative variables:

$$
\begin{aligned}
c_{t}^{R} & =\frac{\kappa_{C N}}{K} \eta a_{N, t}^{R}+\frac{\kappa_{C T}}{K}(\omega-1)(1-\eta) a_{T, t}^{R}, \\
l_{t}^{R} & =\frac{\kappa_{L N}}{K} \eta a_{N, t}^{R}+\frac{\kappa_{L T}}{K}(\omega-1)(1-\eta) a_{T, t}^{R}, \\
y_{t}^{R} & =\frac{\kappa_{L N}+K}{K} \eta a_{N, t}^{R}+\frac{\kappa_{L T}+\frac{K}{\omega-1}}{K}(\omega-1)(1-\eta) a_{T, t}^{R}, \\
q_{t} & =\frac{\kappa_{Q N}}{K} \eta a_{N, t}^{R}+\frac{\kappa_{Q T}}{K}(\omega-1)(1-\eta) a_{T, t}^{R}, \\
c_{T, t}^{R} & =\left(\frac{\kappa_{C N}}{K}-\theta \frac{\kappa_{Q N}}{K}\right) \eta a_{N, t}^{R}-\left(\frac{\kappa_{C T}}{K}+\theta \frac{\kappa_{Q T}}{K}\right)(\omega-1)(1-\eta) a_{T, t}^{R},
\end{aligned}
$$

where

$$
\begin{aligned}
\kappa_{C N} & \equiv 1+\phi_{C}(1-\theta+\eta \theta)+[1+(\omega-1)(1-\eta)] \psi, \quad \kappa_{C T} \equiv-\left(\eta \psi+\phi_{C}\right), \\
\kappa_{L N} & \equiv \eta-\rho(1-\theta+\eta \theta)-[1+(\omega-1)(1-\eta)] \phi_{L}, \quad \kappa_{L T} \equiv \rho+\eta \phi_{L}, \\
\kappa_{Q N} & \equiv \rho \kappa_{C N}+\phi_{C} \kappa_{L N}=\rho+\eta \phi_{C}+[1+(\omega-1)(1-\eta)]\left(\psi \rho-\phi_{C} \phi_{L}\right), \\
\kappa_{Q T} & \equiv \rho \kappa_{C T}+\phi_{C} \kappa_{L T}=-\left(\psi \rho-\phi_{C} \phi_{L}\right) \eta, \\
K & \equiv \kappa_{L T} \kappa_{C N}-\kappa_{C T} \kappa_{L N} \\
& =\rho+\eta \phi_{L}+\eta\left(\eta \psi+\phi_{C}\right)+[(1-\eta) \omega+\eta \theta]\left(\psi \rho-\phi_{L} \phi_{C}\right) .
\end{aligned}
$$

By examining the above equations, I investigate implications of the general CES specification in traded good aggregation and of nonseparability in utility. First, in order to understand the implications of the general CES, I examine a special case of CES, Cobb-Douglas, and point out its limitations. ${ }^{16}$ With Cobb-Douglas, $\omega=1$, country-specific productivity shocks in the traded good

\footnotetext{
${ }^{15}$ I use this specification for quantitative discussions.

${ }^{16}$ Assuming the other extreme case, namely perfect substitution between Home and Foreign traded goods, is becoming less common since two-way trade contradicts the assumption of $\omega=\infty$.
} 
sector, $a_{T, t}^{R}$, will not affect total consumption unlike nontraded good sector productivity shocks, $a_{N, t}^{R}$. This is true not only for total consumption but also for other variables including traded good consumption and real exchange rates. Stockman and Tesar (1995) find that their model is missing some source of nation-specific variation in consumption of traded goods. However, this is partly because they assume that the elasticity of substitution between Home traded goods and Foreign traded goods is unity. As the value of $\omega$ is commonly believed to lie between about 0.8 and 6 , the Cobb-Douglas specification seems reasonable. However, as shown here, if the productivity level in the traded good sector is more volatile than in the nontraded good sector, the Cobb-Douglas assumption eliminates variation in consumptions resulting from the productivity difference in the HOme and Foreign traded good sectors.

In addition, there is no Balassa-Samuelson effect if $\omega=1$. With typical values for other parameters, $\omega>1$ is a necessary condition for real exchange rates to appreciate in response to positive productivity shocks in the traded good sector. Both relative consumption and real exchange rates are linear functions of the relative nontraded good sector productivity if $\omega=1$. This leads to a perfect correlation between relative consumption and real exchange rates even with nonseparable utility function.

The general CES specification is also important for matching the basic moments of the data. In order to have a non-unity consumption correlation it is necessary to have $\operatorname{Var}\left(c_{t}^{R}\right)>0$. In order to reduce consumption correlation, $\operatorname{Var}\left(c_{t}^{R}\right)$ has to increase more than $\operatorname{Var}\left(c_{t}^{W}\right)$ with changes in parameter values. With high $\omega$, it is easy to generate low consumption correlation when the variance of $a_{T, t}^{R}$ is high. If the Armington elasticity is as high as $\omega=5$, then it is not so hard to match consumption correlation per se.

While a Cobb-Douglas specification can be qualitatively quite different from the general CES specification, the difference may be small quantitatively if $\omega$ is close to one and/or the relative productivity shocks in the traded good sector are less volatile than other shocks. However, a Cobb-Douglas specification can eliminate the transmission of relative productivity shocks in the trade good sector to consumption and real exchange rates.

Second, nonseparability implies nonzero $\phi_{C}$ and $\phi_{L}$. The condition $\phi_{C} \neq 0$ is necessary in order to break the perfect correlation between relative consumption and real exchange rates in this class of models because otherwise $q_{t}=\rho c_{t}^{R}$. Except for this, nonseparability does not seem to play an important role in the transmission mechanism qualitatively. However, as it turns out, it plays an important role in portfolio allocation. In addition, nonseparability can of course alter the business cycle properties though it may not be significant enough to solve existing puzzles in open economy macroeconomics.

\section{The Optimal Portfolio}

I next demonstrate the existence of the supporting equity portfolio in this economy for the allocation derived under the complete asset market assumption. I also show that the nonexistence of the supporting portfolio with some combination of parameter values. The literature has not paid much attention to the case of nonexistence. However, this case might be important in explaining the lack of international risk sharing. Before going to the discussion of nonexistence of the supporting portfolio, I first show the supporting portfolio when it exists. 
Households first allocate a portion of equity portfolio, $\eta$, to the nontraded good sector and $1-\eta$ to the traded good sector. Note that $\eta$ is also the weight of nontraded goods in total consumption. This allocation is obvious because the value of firms depends on the future sales and profit margin, but the margin in each sector is identical and the future sales share of each sector is the same as the consumption share. Then, Home households allocate a portion, $\delta_{N}$, of nontraded good sector equity portfolio to Foreign equities and $\delta_{T}$ of traded good sector equity portfolio to Foreign.For example, the optimal weight on Home traded good sector equities in the total equity portfolio of the Home residence is $\eta \times\left(1-\delta_{T}\right)$. Using the above notation, the relative budget constraint becomes

$$
\begin{aligned}
& {\left[c_{t}^{R}-\eta\left(p_{N, t}+y_{N, t}\right)-(1-\eta)\left(p_{T, t}+y_{T, t}\right)\right] } \\
= & \frac{1}{1-n} \delta_{N} \eta(1-\zeta)\left[\left(p_{N, t}^{*}+y_{N, t}^{*}+q_{t}\right)-\left(p_{N, t}+y_{N, t}\right)\right] \\
& \quad+\frac{1}{1-n} \delta_{T}(1-\eta)(1-\zeta)\left[\left(p_{T, t}^{*}+y_{T, t}^{*}+q_{t}\right)-\left(p_{T, t}+y_{T, t}\right)\right] .
\end{aligned}
$$

The left-hand side of this equation is the difference between consumption expenditure and income of Home households if there were no assets traded under the optimal allocation. In order to achieve the optimal allocation, assets trade should offset this difference. The right hand side is the value of Home households' gain from asset trade as Home households exchange $\delta_{N}$ of Home firm equities in nontraded good sector to acquire $\delta_{N}$ of Foreign firm equities in the nontraded good sector and so on. For example, $p_{T, t}^{*}+y_{T, t}^{*}+q_{t}$ is the revenue of the foreign firms in traded good sector in terms of Home consumption goods, and $1-\zeta$ is the capital share. Hence, the profit is the product of these two. ${ }^{17}$ Then, the equity portfolio weights $\delta_{T}$ and $\delta_{N}$ can be determined from equation (31) because it must hold $\forall a_{N, t}^{R}$ and $a_{T, t}^{R}$.

Rewriting the above equation in terms of $l_{t}^{R}, c_{t}^{R}$, and exogenous variables, $a_{N, t}^{R}$, and $a_{T, t}^{R}$ gives

$$
\begin{aligned}
& (1-n)\left(\rho c_{t}^{R}+\phi_{C} l_{t}^{R}+\psi l_{t}^{R}+\phi_{L} c_{t}^{R}+l_{t}^{R}-c_{t}^{R}\right) \\
=\delta_{N} & \eta(1-\zeta)\left[(1-\theta)\left(\rho c_{t}^{R}+\phi_{C} l_{t}^{R}+\psi l_{t}^{R}+\phi_{L} c_{t}^{R}-a_{N, t}^{R}\right)-\rho c_{t}^{R}-\phi_{C} l_{t}^{R}+c_{t}^{R}\right] \\
& \quad+\delta_{T}(1-\eta)(1-\zeta)(1-\omega)\left(\psi l_{t}^{R}+\phi_{L} c_{t}^{R}-a_{T, t}^{R}\right) .
\end{aligned}
$$

Since $l_{t}^{R}$ and $c_{t}^{R}$ are given by equations (26) and (27), it is straightforward to solve for $\delta_{N}$ and $\delta_{T}$ except for the case with $\omega=1$, for which $\delta_{T}$, the portfolio weight for traded good sector equities, cannot be determined.

\footnotetext{
${ }^{17}$ While there are capital gains from the portfolio, the flexible price assumption allows me to focus on income from dividends. As the current budget constraint is satisfied in each period, the solution from this equation leads to the supporting portfolio. In the separate Appendix, I describe the budget constraint in terms of the total return.
} 


$$
\begin{aligned}
& \delta_{T}=\frac{1-n}{1-\zeta}\left\{1+\frac{(1-\eta)(\theta-1) \frac{\phi_{C}}{\rho}}{(1-\eta)(\theta-1)\left(1+1 / \varepsilon_{l, w}\right)+\eta\left[\frac{\psi+1}{\rho}-\left(1+1 / \varepsilon_{l, w}\right)\right]}\right\} \text { for } \omega \neq 1, \\
& \delta_{N}=\frac{1-n}{1-\zeta}\left\{1+\frac{(1-\eta)(\theta-1) \frac{\phi_{C}}{\rho}-\frac{\psi+1}{\rho}+\left(1+1 / \varepsilon_{l, w}\right)}{(1-\eta)(\theta-1)\left(1+1 / \varepsilon_{l, w}\right)+\eta\left[\frac{\psi+1}{\rho}-\left(1+1 / \varepsilon_{l, w}\right)\right]}\right\},
\end{aligned}
$$

where $\varepsilon_{l, w}=\frac{\rho}{\psi \rho-\phi_{C} \phi_{L}}$ is a Frisch elasticity of labor supply. When the denominator is zero, there is no supporting portfolio.

This solution nests several important results as special cases. In the case of the separable utility case, where $\phi_{C}=0$, then $\delta_{T}=\frac{1-n}{1-\zeta}$. That is, "The International Diversification Puzzle Is Worse Than You Think" situation. In the case of an endowment economy, $\delta_{T}=1-n$ and $\delta_{N}=(1-n)\left[1+\frac{1-1 / \rho}{(1-\eta)(\theta-1)-\eta(1-1 / \rho)}\right]$, which coincide with Baxter et al. (1998). ${ }^{18}$ Without nontraded goods, $\eta=0, \delta_{T}=\frac{1-n}{1-\zeta}\left(1+\frac{\phi_{C} / \rho}{1+1 / \varepsilon_{l, w}}\right)$, for $\omega \neq 1$, which is a general result of Jermann (2002). ${ }^{19}$

There are four important implications regarding the portfolio allocation. First, when the elasticity of substitution between home and foreign traded goods is unity, or $\omega=1$, the result is similar to Cole and Obstfeld (1991), where they find that there is no gain from equity trade. However, the existence of the nontraded good sector with $\omega=1$ has an interesting implication. If there is only one mutual fund for each country, which implies $\delta^{T}=\delta^{N}$, then the equity portfolio weight for foreign equity as a whole is $\delta^{N}$. If $\theta=1$ for example, then the portfolio weight is 'super' home biased, meaning that home would go short in foreign equity. Also, as shown in Engel and Matsumoto (2006), if $\omega$ is close to unity, then price rigidity is an important factor in determining equity portfolio allocation. Since empirical estimates of $\omega$ are often close to one, short-run effects of price rigidity deserve closer attention.

Second, $\omega$ has quite an important role in terms of determinacy of the traded good sector equity portfolio but does not have any further effect on the portfolio weight in the case $\omega \neq 1$. This is because the shocks from the relative productivity in the traded good sector are transmitted to consumption and labor with the common coefficient, $\omega-1$, as in equations (26) and (27). In other words, by defining $\dot{a}_{t}^{R}=(\omega-1) a_{t}^{R}, \omega$ becomes a part of an exogenous variable. Because the complete market supporting portfolio offsets the effect from relative shocks, $\omega$ does not enter into the portfolio function itself. The traded goods equity portfolio, $\delta_{T}$, without a nontraded good sector, $\eta=0$, is then identical to that in Jermann (2002) who assumes homogeneous traded goods, i.e., $\omega=\infty$. However, my finding shows that his result is robust to variations in the elasticity of substitution between home goods and foreign goods except for the Cobb-Douglas case.

\footnotetext{
${ }^{18}$ Baxter et al. (1998) nest Stockman and Dellas (1989).

${ }^{19}$ Jermann (2002) looks at the case where all traded goods are homogeneous, i.e., $\omega=\infty$.
} 
Third, the optimal portfolio is extremely biased towards either Home or Foreign under nonseparability as depicted in Figures $1-3 .{ }^{20}$ Baxter et al. (1998) find that the optimal equity portfolio in the traded good sector is a world diversified portfolio. In my setting with a production economy and separable utility, the portfolio allocation of the traded good sector is similar to that of Baxter and Jermann (1997), where home owns more foreign equity. However, once I introduce nonseparability, then the equity portfolio in the traded good sector behaves similarly to the nontraded good sector. As shown, the existence of a nontraded good sector affects equity portfolio in the traded good sector. Most important, with nonseparability, I can overturn the previous result that the optimal portfolio of the traded good sector equities is well diversified. We can no longer dismiss the claim that existence of nontraded goods explains the home bias puzzle, since the validity of the claim depends on the model parameters. On the hand, this result alone does not provide a solution to the home bias puzzle.

Finally, I should note that the denominator in equations (33) and (34),

$$
(1-\eta)(\theta-1)\left(1+\varepsilon_{l, w}\right)+\eta\left[\frac{\psi+1}{\rho}-\left(1+\varepsilon_{l, w}\right)\right]
$$

can be zero given reasonable parameter values. As $\varepsilon_{l, w}$ does not depend on $\theta$, this denominator is a linear function of $\theta$ and can become zero as $\theta$ changes its value. It is easy to see with separable utility that the zero denominator case is empirically relevant. The denominator can be rewritten as $(\psi+1)[(1-\eta)(\theta-1)+\eta(1 / \rho-1)]$ under separable utility. What are the reasonable parameter values? The nontraded good sector weight, $\eta$, is typically 0.5 to 0.8 , the estimate of the elasticity of substitution between traded and nontraded goods, $\theta$, ranges from 0.44 to 1.44 as discussed in the following section, and the inverse of the elasticity of intertemporal substitution of consumption, $\rho$, ranges from .5 to 10 . With these parameter values, the sign of denominator can be either positive or negative. This can generate an extremely biased portfolio. Baxter et al. (1998) find similar results regarding the nontraded good sector equity portfolio. They show that the equity portfolio in the nontraded good sector is extremely sensitive to the elasticity of substitution between traded and nontraded goods. ${ }^{21}$ However, in the case of nonseparability, this sensitivity is also true of the portfolios of both traded and nontraded good sector equities as depicted in Figure 1. The portfolio is also sensitive to changes in other parameters as demonstrated in Figure 2 with respect to the elasticity of substitution between leisure and consumption, $\mu$, and in Figure 3 with respect to the coefficient of relative risk aversion, $\sigma$. The denominator becomes zero when the relative return of traded good sector equities and that of nontraded good sector equities are linearly dependent. In the case of separability, this happens when the relative return of nontraded good sector equities is constant. When the denominator is zero, then there exists no supporting equity portfolio.

The nonexistence of the supporting portfolio and the extremely biased portfolio around this nonexistence point has further implications. Even if the number of assets is sufficient to span all the shocks, it may not be possible to achieve the complete market allocation since small market frictions such as short-selling constraints can prevent agents from holding the complete market allocation supporting portfolio that requires an extreme short position. In fact, there are many different assets in reality, but asset returns might be highly correlated with each other, and the optimal portfolio without market frictions might require an extremely biased position in one of the assets. In this case, transaction costs or some other frictions could explain imperfect risk sharing. This suggests that in

\footnotetext{
${ }^{20}$ The parameter values used in the figures are in Table 2 unless otherwise noted in figures.

${ }^{21}$ If $\zeta=0$, then the portfolio will coincide with that in Baxter et al. (1998).
} 
building a model with incomplete asset markets, it is more realistic to assume certain frictions rather than arbitrarily missing assets as has been common practice.

As shown in the next section, the model cannot generate quantitatively reasonable portfolio weights of traded sector and nontraded sector simultaneously. For example, when the parameter values are set so that the weight on foreign equities in the traded good sector is around 0.1 , that of the nontraded good sector tends to be either more than one or less than 0 . On the other hand, any firms in reality are affected by both traded and nontraded good sector productivity shocks, and it might not be quite right to look at an individual sector per se. Instead, we might have to look at the share of traded and nontraded components in a firm. Nonetheless, as the result is very sensitive to changes in parameter values, the results suggest the need for further investigation.

\section{Calibration}

As open economy general equilibrium models with portfolio choice tend to be simple, these models have not been evaluated seriously in terms of business cycle properties. This is not a problem as the main purpose of these models is to examine basic mechanism of portfolio allocations. Nonetheless, business cycle properties can highlight shortcomings of a model and provide future direction. Table 1 shows moments from the data and the model, and I cannot claim that the model is more successful than Stockman and Tesar (1995). Although the model is more general than Baxter et al. (1998), Jermann (2002) and so on, the sources of the fluctuation are still solely productivity shocks. As Stockman and Tesar improve the model performance by adding tastes shocks, the model requires additional shocks to match the data better.

\section{A. The Choice of Parameter Values}

The choice of parameter values in this model is not easy as perturbations in these values can sometimes result in significant changes in moments and portfolio shares. I try to use established values as often as possible.

The share of the Home country is assumed to be 0.5 . The value of $\bar{C}=\bar{L}$ is set to be 0.33 assuming one third of non-sleeping time is allocated to work. In this regard, I also set the share of consumption in utility $s_{c}$ to be 0.33 , which implies $\gamma=0.33$. The share of nontraded goods in consumption is assumed to be 0.75 .

I follow the parameter values of Jermann (2002) for $\sigma$ and $\mu$. The coefficient of relative risk aversion with respect to utility, $\sigma$, is assumed to be 5 and the elasticity of substitution between leisure and consumption, $\mu$, is set to be $5 .^{22}$ As these values have a wide range of estimates, the alternative parameter values of $\sigma=1$ and $\mu=1$ are examined respectively.

The elasticity of substitution between nontraded goods and traded goods, $\theta$, is set to be 0.7 . Ostry and Reinhart (1992) estimate $\theta$ in the range 1.22-1.28 for all regions and 0.66-1.44 for each individual region. Stockman and Tesar (1995) find that $\theta=0.44$ and claim that $\theta$ tends to be low among

${ }^{22}$ Jermann (2002) picked $\mu=5$ as his baseline because empirical studies find $\mu$ in the range $(0,5)$, but others including Stockman and Tesar, Backus et al. (1992), and Benigno and Toenissen (2006) use a Cobb-Douglas specification, which implies $\mu=1$. 
industrialized countries. Mendoza (1995) estimates $\theta=0.74$ for industrialized countries. While $\theta$ can potentially alter the moments in general, given other parameter values in this section, important correlations hardly responds to changes in $\theta$. The elasticity of substitution between Home and Foreign traded goods or Armington elasticity, $\omega$, is assumed to be 2 following Ruhl (2005). As the share of traded goods in consumption is 0.25 , this may be relatively low. ${ }^{23}$ In order to compensate for the low share of the traded sector, I use $\omega=5$ as an alternative so that expenditure switching effect in the total consumption is not too low.

While the optimal portfolio does not depend on the variance of underlying shocks or $\omega$, business cycle properties do. I estimate the variance-covariance matrix of vector $a$ using labor productivity of G7 countries, treating the US as Home and the G6 as Foreign by imposing symmetry. Notice that my estimate of the variance of productivity in the traded sector is much higher than the one in the nontraded sector.

$$
\operatorname{Var}\left(a_{t}\right)=\left(\begin{array}{cccc}
0.999 & 1.568 & 0 & 0 \\
1.568 & 10.894 & 0 & 0 \\
0 & 0 & 0.692 & 0.714 \\
0 & 0 & 0.714 & 6.054
\end{array}\right)
$$

where, $a_{t}=\left(a_{N, t}^{W}, a_{T, t}^{W}, a_{N, t}^{R}, a_{T, t}^{R}\right)$. This implies

$$
\operatorname{Var}\left(\begin{array}{c}
a_{N, t} \\
a_{T, t} \\
a_{N, t}^{*} \\
a_{T, t}^{*}
\end{array}\right)=\left(\begin{array}{cccc}
1.17 & 1.75 & 0.83 & 1.39 \\
1.75 & 12.40 & 1.39 & 9.38 \\
0.83 & 1.39 & 1.17 & 1.75 \\
1.39 & 9.38 & 1.75 & 12.40
\end{array}\right)
$$

I also calculate variance-covariance matrices of total factor productivity based on the results from Stockman and Tesar (1995), Tesar (1993), and Benigno and Toenissen (2006). Their estimates are quite different. ${ }^{24}$ Stockman and Tesar claim that the persistence of the traded good sector productivity is low. As a result, even though the variance of the innovation to productivity is larger in the traded good sector, the variance of productivity itself is smaller. On the other hand, Benigno and Toenissen find persistent productivity as well as volatile innovation in the traded good sector, implying volatile productivity in that. My estimate of labor productivity is quantitatively in the middle of their estimates. I use the estimate from Stockman and Tesar (1995) as an alternative as their estimates of productivity variance is quite high in the nontraded good sector.

\section{B. Discussion of Results}

Table 1 shows moments from the data and various results from the model with alternative parameter values. Given the model is solely driven by productivity shocks, it is natural that this model fails to match the data. The benchmark model has a high cross-country consumption correlation and a relatively high Backus-Smith correlation. The optimal portfolio weight for the Foreign traded good sector equites is 14 percent, which itself is a realistic number. However, the weight for the Foreign

\footnotetext{
${ }^{23}$ Chari, Kehoe and McGrattan (2002) and Engel and Matsumoto (2006) use $\omega=1.5$ in models without nontraded goods.

${ }^{24}$ They use different detrending methods, estimates of total factor productivity, and data.
} 
Table 1. Calibration

\begin{tabular}{|c|c|c|c|c|c|c|c|c|c|}
\hline & & $\mathrm{Da}$ & & & & & Model & & \\
\hline & $\mathrm{US}^{\mathrm{a}}$ & $\mathrm{US}^{\mathrm{b}}$ & $G 6^{a, c}$ & $\mathrm{G} 6^{\mathrm{b}, \mathrm{c}}$ & 1 & 2 & 3 & 4 & $5^{\mathrm{e}}$ \\
\hline$\sigma$ (risk aversion) & & & & & 5.00 & 5.00 & 5.00 & 1.00 & 5.00 \\
\hline$\mu$ (elasticity btw. & $C$ and $L$ & & & & 5.00 & 5.00 & 1.00 & 5.00 & 5.00 \\
\hline$\omega$ (Armington ela & ticity) & & & & 2.00 & 5.00 & 2.00 & 2.00 & 2.00 \\
\hline Standard Deviation & & & & & & & & & \\
\hline Consumption $(c)$ & 1.06 & 1.34 & 0.80 & 1.20 & 0.91 & 1.04 & 0.85 & 1.68 & 1.99 \\
\hline Output $(y)$ & 1.61 & 2.10 & 1.00 & 1.39 & 1.03 & 1.31 & 0.99 & 1.76 & 1.83 \\
\hline Labor $(l)$ & 1.32 & 1.76 & 0.68 & 1.15 & 0.52 & 0.76 & 0.55 & 0.33 & 1.17 \\
\hline Wage $(w)$ & 1.11 & 1.39 & 1.17 & 1.68 & 1.40 & 1.40 & 1.39 & 1.40 & 2.93 \\
\hline$\left(c_{N}\right)^{\mathrm{f}}$ & 0.86 & 1.13 & 0.60 & 1.11 & 0.70 & 0.87 & 0.65 & 1.41 & 2.36 \\
\hline$\left(c_{T}\right)$ & 1.13 & 1.48 & 0.94 & 1.25 & 2.25 & 2.30 & 2.21 & 2.94 & 1.31 \\
\hline$\left(y_{N}\right)^{\mathrm{f}}$ & 1.08 & 1.48 & 0.60 & 1.02 & 0.70 & 0.87 & 0.65 & 1.41 & 2.36 \\
\hline$\left(y_{T}\right)$ & 3.03 & 3.97 & 2.11 & 2.63 & 3.23 & 5.88 & 3.13 & 3.74 & 3.75 \\
\hline Domestic Correlatio & & & & & & & & & \\
\hline$\rho(c, y)$ & 0.82 & 0.80 & 0.81 & 0.85 & 0.81 & 0.22 & 0.82 & 0.94 & 0.87 \\
\hline$\rho(c, l)$ & 0.58 & 0.57 & 0.58 & 0.73 & -0.99 & -0.95 & -0.99 & 0.81 & -0.99 \\
\hline$\rho(y, l)$ & 0.82 & 0.80 & 0.60 & 0.63 & -0.71 & 0.11 & -0.74 & 0.96 & -0.81 \\
\hline$\rho(w, l)$ & 0.10 & -0.05 & -0.10 & 0.13 & -0.95 & -0.59 & -0.96 & 0.86 & -0.97 \\
\hline$\rho\left(c_{N}, c_{T}\right)$ & 0.65 & 0.59 & 0.78 & 0.79 & 0.39 & 0.43 & 0.33 & 0.76 & 0.63 \\
\hline$\rho\left(y_{N}, y_{T}\right)$ & 0.72 & 0.71 & 0.63 & 0.64 & 0.06 & -0.75 & 0.16 & -0.52 & 0.34 \\
\hline$\rho\left(l_{N}, l_{T}\right)$ & 0.74 & 0.70 & 0.55 & 0.67 & 0.16 & -0.45 & 0.17 & 0.56 & -0.20 \\
\hline Cross Country Corre & ation & & & & & & & & \\
\hline$\rho\left(c, c^{*}\right)$ & 0.49 & 0.60 & & & 0.85 & 0.39 & 0.90 & 0.87 & 0.28 \\
\hline$\rho\left(y, y^{*}\right)$ & 0.79 & 0.68 & & & 0.43 & -0.12 & 0.39 & 0.71 & 0.51 \\
\hline$\rho\left(c_{N}, c_{N}^{*}\right)$ & 0.39 & 0.67 & & & 0.66 & 0.06 & 0.70 & 0.77 & 0.28 \\
\hline$\rho\left(c_{T}, c_{T}^{*}\right)$ & 0.46 & 0.49 & & & 0.99 & 0.90 & 1.00 & 0.98 & 0.65 \\
\hline$\rho\left(l, l^{*}\right)$ & 0.65 & 0.66 & & & 0.74 & -0.20 & 0.83 & 0.37 & 0.15 \\
\hline$\rho\left(w, w^{*}\right)$ & 0.11 & 0.21 & & & 0.87 & 0.87 & 0.89 & 0.88 & 0.42 \\
\hline$\rho\left(y_{N}, y_{N}^{*}\right)$ & 0.63 & 0.50 & & & 0.66 & 0.06 & 0.70 & 0.77 & 0.28 \\
\hline$\rho\left(y_{T}, y_{T}^{*}\right)$ & 0.75 & 0.71 & & & -0.03 & -0.71 & -0.01 & 0.22 & -0.80 \\
\hline$\rho\left(c^{R}, q\right)$ & & & & & 0.85 & 0.52 & 0.94 & 0.97 & 0.99 \\
\hline Share of Foreign Eq & & & & & & & & & \\
\hline$\delta_{T}$ & & & & & 0.14 & 0.14 & 1.32 & 1.21 & 0.14 \\
\hline$\delta_{N}$ & & & & & -3.65 & -3.65 & -0.02 & -0.59 & -3.65 \\
\hline
\end{tabular}

${ }^{a}$ Bandpass(1.5 8) filtered series.

${ }^{\mathrm{b}}$ First differenced series.

c G6 countries consist of Japan Germany, France, Italy, UK, and Canada.

${ }^{\mathrm{d}}$ Other model parameter values are followings:

- share of Home country in world population $n=0.5$;

- share of working hours in non-sleeping time $\bar{L}=\bar{C}=0.33$;

- share of consumption in utility $s_{c}=0.33$ implying $\gamma=0.33$;

- share of nontraded goods in consumption $\eta=0.75$;

- elasticity substitution between $C_{N T}$ and $C_{T} \theta=0.7$

${ }^{\text {e }}$ Alternative variance-covariance matrix.

${ }^{\mathrm{f}}$ In theory $y_{N}=c_{N}$, but this is not the case in the data. 
nontraded good sector of negative 365 percent is unreasonable. Changing the Armington elasticity to alternative value $(\omega=6)$ does not change the portfolio weights but lowers the cross country consumption correlation and the Backus-Smith correlation. However, the cross-country output correlation becomes too low, creating another problem. If we assume Cobb-Douglas aggregation of consumption and leisure, $\mu=1$, Model 3 behaves worse in most aspects than the benchmark model.

One of the problems with this model is the fact that it tends to generate a negative correlation between labor and consumption. This is due to the fact that in response to positive technology shocks, households increases both consumption and leisure. The log utility assumption $(\sigma=1)$ induces positive correlation between labor and consumption but worsens some other aspects. This suggests the need for other shocks than productivity.

Finally, using the alternative productivity process where the nontraded good sector is relatively volatile, Model 6 can generate a low cross-country consumption correlation. In this model, the cross-country consumption correlation can be smaller than the cross-country output correlation if and only if $\operatorname{Var}\left(c_{t}^{R}\right)>\operatorname{Var}\left(y_{t}^{R}\right)$. In fact, within usual ranges of parameter values, it is always the case that $\kappa_{C T}<\kappa_{L T}+K /(\omega-1)$. This implies that the coefficient on relative productivity in the traded good sector, $a_{t}^{R}$, is greater for output equation (28) than for consumption equation (26). From these equations, it becomes clear that $\kappa_{C N}>\kappa_{L N}+K$ is a necessary condition for $\operatorname{Var}\left(c_{t}^{R}\right)>\operatorname{Var}\left(y_{t}^{R}\right)$. This in turn implies that the variance of the relative productivity in the nontraded good sector must be greater than that in the traded good sector. This is why if I use an alternative variance-covariance matrix, the model can generate a low cross-country consumption correlation. On the other hand, this kind of variance-covariance matrix tends to generate a higher correlation between relative consumption and real exchange rates.

Overall, it is apparent that one of the simplest international business cycle models with relatively general utility function performs poorly as the model cannot match the key moments of the data simultaneously. Some of the issues raised in Stockman and Tesar (1995) can be solved only by generating other problems. This is not surprising since this model is driven only by labor productivity shocks. Demand shocks such as monetary shocks and government spending shocks seem to be needed to match the data. However, this model still provides useful insights into the international transmission mechanism of productivity shocks. For example, the general CES specification can recover many transmission channels eliminated by a Cobb-Douglas specification. Nonseparability in utility is a necessary condition for non-unity correlation between relative consumption and real exchange rates. Nonseparability can also alter business cycle properties quantitatively.

\section{Conclusion}

This paper presents a two-country, two-sector production economy model with flexible prices. It nests the models of Stockman and Dellas (1989), Baxter et al. (1998), and Jermann (2002) as special cases. I find that the presence of nontraded goods and nontraded factors with nonseparable utility can be a potential solution to the equity home bias puzzle. The optimal portfolio of traded good sector equities is no longer a well diversified world portfolio, overturning the finding of Stockman and Dellas (1989), and Baxter et al. (1998). In addition, the quantitative results suggest that this class of model falls short of matching the data. Therefore, further research is needed to determine whether nontraded goods can indeed explain the home bias puzzle. 
Since the optimal portfolio that supports the complete market allocation in the model is often extremely biased, the lack of international risk sharing in reality may be due to minor market frictions, which prevents agents from taking these extreme positions, rather than due to missing asset markets. This suggests that a realistic incomplete market model should adopt market frictions rather than eliminate an asset arbitrarily. This theoretical conclusion is in line with the empirical findings of Lewis (1996).

Another important finding regarding international portfolio choice is that the elasticity of substitution between home and foreign traded goods is an important factor for determinacy of the traded good sector equity portfolio. If the elasticity is unity, then the terms of trade play the role of insurance and any traded good sector equity portfolio will support the optimal allocation. ${ }^{25}$ This issue is discussed in Engel and Matsumoto (2006), who find that if the elasticity between home and foreign traded goods is close to unity then price stickiness plays an important role for the optimal portfolio choice. This finding calls for introducing price rigidity into the model.

This model performs poorly in matching international real business cycle features. For example, while assuming nonseparability can alter business cycle properties, it fails to match all the moments or even only important ones simultaneously. This finding is not surprising as the model is driven solely by productivity shocks. Nevertheless, the closed form solution provides some insights into the international transmission mechanism.

Future work should take into account these findings. Nonseparability, which does not help match business cycle properties in a simple setup, can be a potentially important factor in explaining portfolio choice. Introducing market frictions in a model seems to be a more reasonable way to explain the lack of international risk sharing than eliminating assets. Price rigidity can be an important factor to explain home bias if the elasticity of substitution between home and foreign traded goods is close to unity. Finally, while the elasticity of substitution between home and foreign traded goods does not enter the portfolio weight function, it plays a role for determinacy of the portfolio.

\footnotetext{
${ }^{25}$ However, there is an exception for this: when nontraded good sector equity portfolio cannot support the optimal allocation then no portfolio can support the optimal allocation.
} 
variables

\begin{tabular}{llc}
\hline$n$ & $\begin{array}{l}\text { home population } \\
\beta\end{array}$ & 0.5 \\
$\sigma$ & $\begin{array}{l}\text { discount factor } \\
\text { coefficient of relative risk aversion and inverse of the intertemporal substitution }\end{array}$ & 5 \\
& $\begin{array}{l}\text { with respect to contemporaneous utility } \\
\text { elasticity of substitution between consumption and leisure }\end{array}$ & 5 \\
$\gamma$ & $\begin{array}{l}\text { utility weight on consumption } \\
\text { coefficient of relative risk aversion and inverse of the intertemporal substitution }\end{array}$ & 0.33 \\
$\rho$ & $\begin{array}{l}\text { with respect to consumption } \\
\text { coefficient of relative risk aversion and inverse of the intertemporal substitution }\end{array}$ & 1.78 \\
$\psi$ & $\begin{array}{l}\text { with respect to leisure } \\
\text { steady state share of working hours in non-sleeping hours }\end{array}$ \\
$\bar{L}$ & $\begin{array}{l}\text { elasticity of substitution between traded and nontrded goods } \\
\text { share of nontraded goods in consumption basket }\end{array}$ & 0.33 \\
$\eta$ & $\begin{array}{l}\text { elasticity of substitution between Home goods and Foreign goods } \\
\text { degree of monopolistic power (also related to the labor share) }\end{array}$ & 0.7 \\
$\lambda$ & $\begin{array}{l}\text { the labor share in the national income; } \zeta \approx \frac{\lambda-1}{\lambda} \\
\zeta\end{array}$ & 2 \\
\hline
\end{tabular}

The alternative variance from Stockman and Tesar $(1995)^{26}$

or

$$
\operatorname{Var}(a)=\left(\begin{array}{rrrr}
8.36 & 3.23 & 0 & 0 \\
3.23 & 3.38 & 0 & 0 \\
0 & 0 & 14.3 & -1.22 \\
0 & 0 & -1.22 & 10.7
\end{array}\right)
$$

$$
\operatorname{Var}\left(\begin{array}{c}
a_{N} \\
a_{T} \\
a_{N}^{*} \\
a_{T}^{*}
\end{array}\right)=\left(\begin{array}{llll}
11.9 & 2.92 & 4.79 & 3.53 \\
2.92 & 6.05 & 3.53 & 0.71 \\
4.79 & 3.53 & 11.9 & 2.92 \\
3.53 & 0.71 & 2.92 & 6.05
\end{array}\right)
$$

${ }^{26}$ I calculate this with $\Omega_{(4,3)}$ altered to $-0.15=\Omega_{(2,1)}$ in equation (14) of Stockman and Tesar. 
Figure 1. Equity Portfolio $\theta$

Portfolio Share of Foreien Equity Benchmark Case
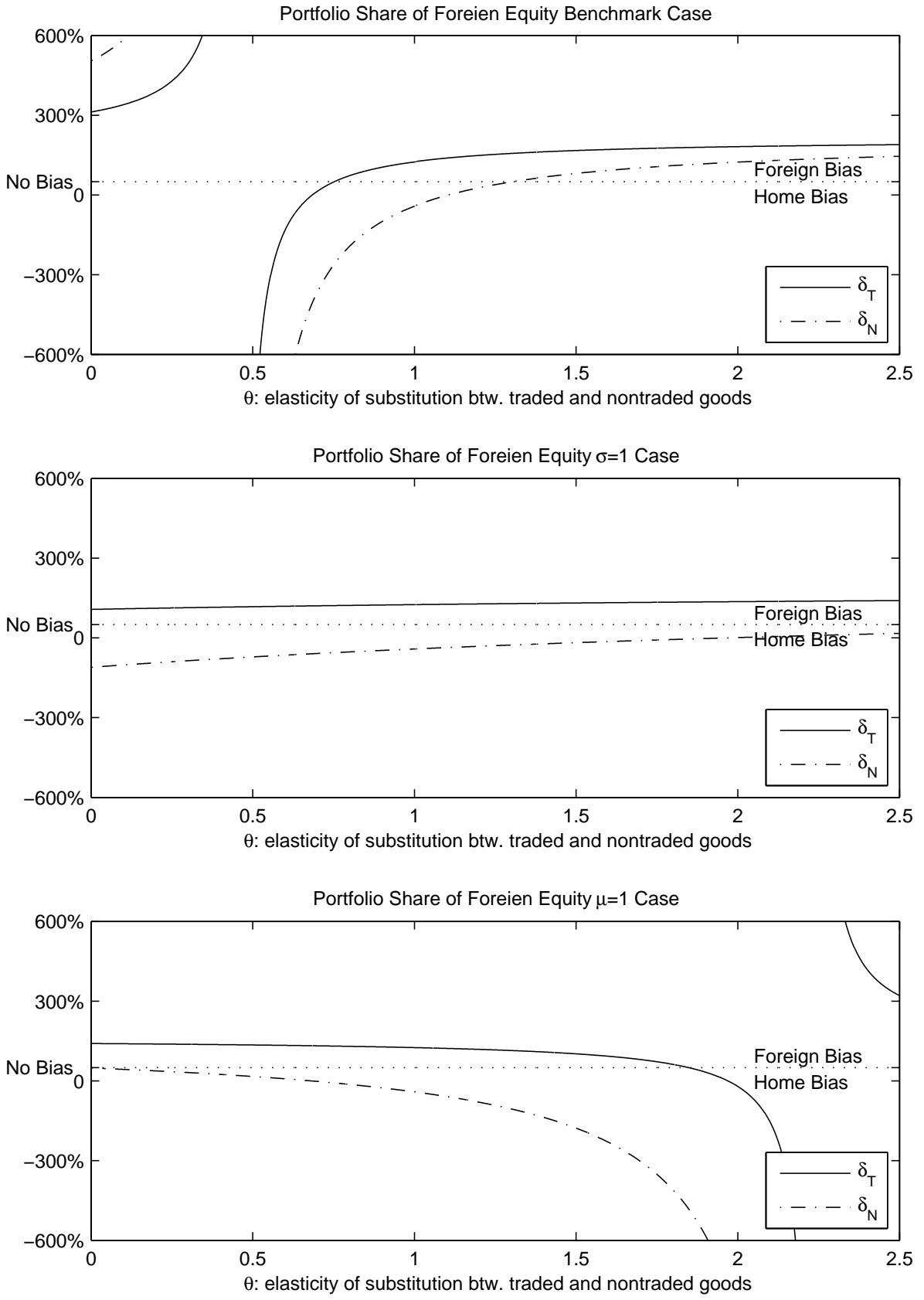
Figure 2. Equity Portfolio $\mu$

Portfolio Share of Foreien Equity Benchmark Case

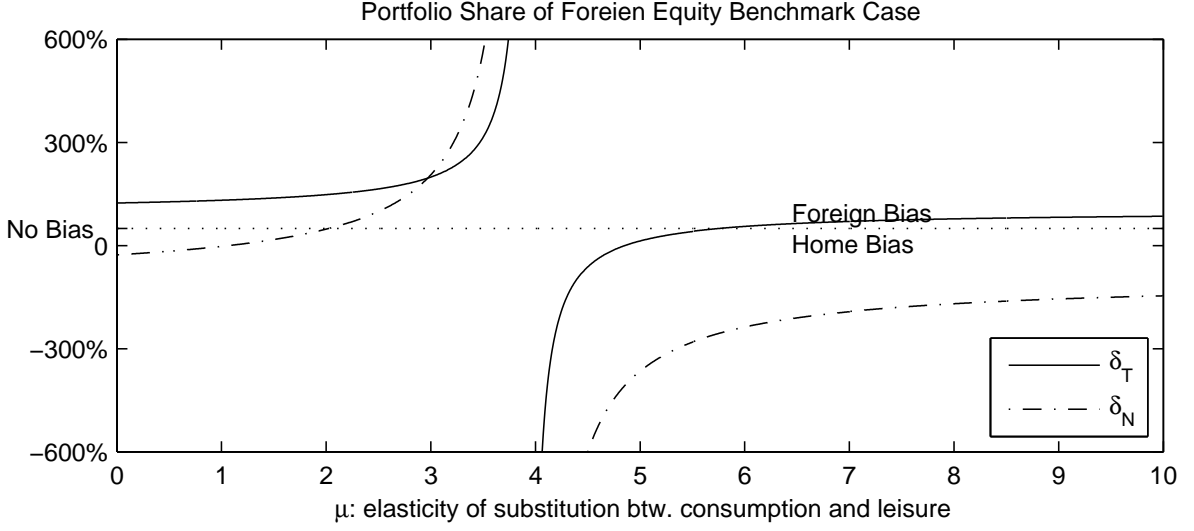

Portfolio Share of Foreien Equity $\sigma=1$ Case
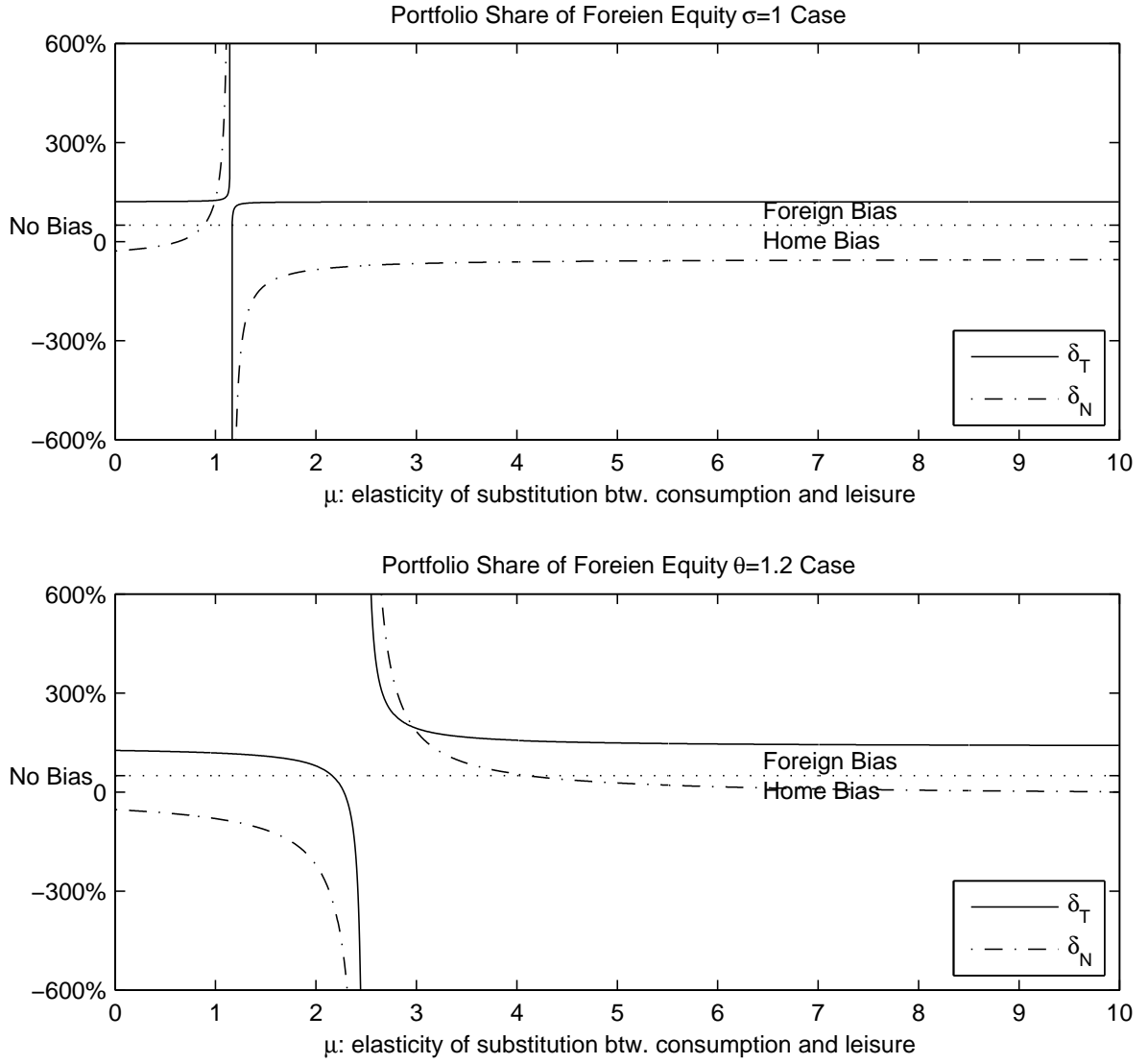
Figure 3. Equity Portfolio $\sigma$

Portfolio Share of Foreien Equity Benchmark Case

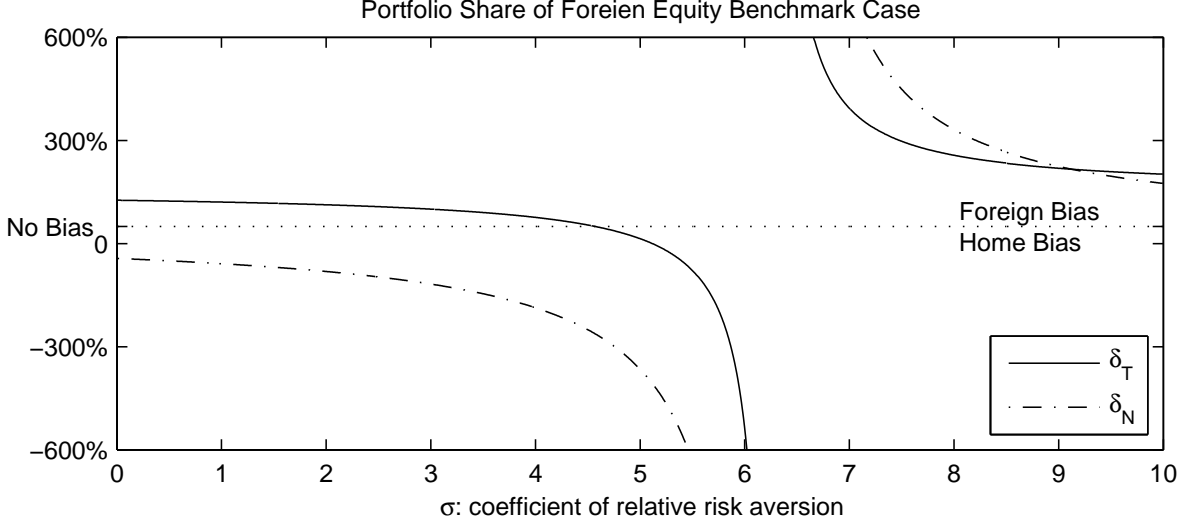

Portfolio Share of Foreien Equity $\mu=1$ Case
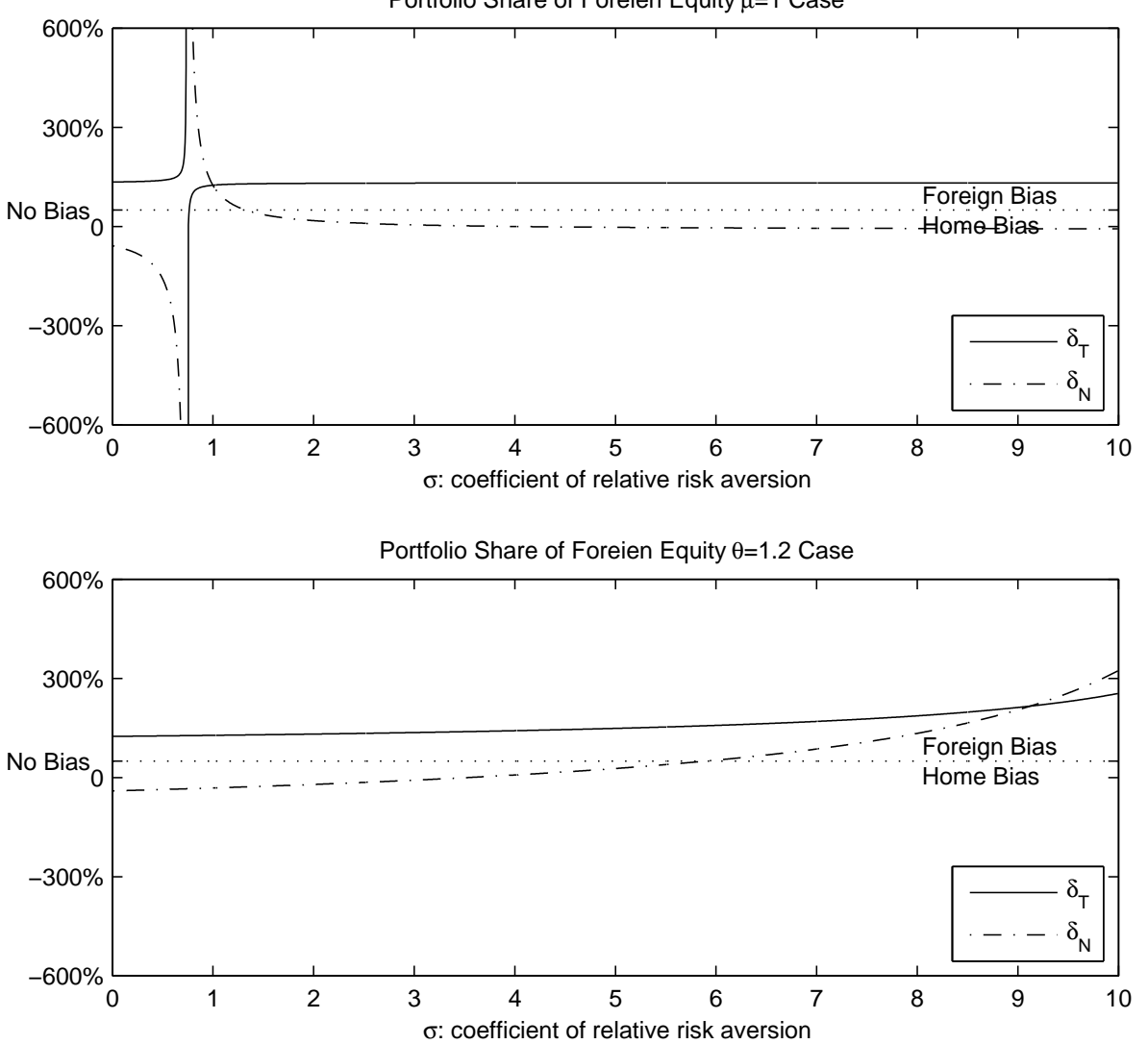


\section{Appendix I. Equilibrium Conditions}

First, it turns out to be convenient to rewrite the budget constraint:

$$
C_{t}(j)+V_{t+1}+H_{t}=V_{t-1} R_{t}+H_{t-1} R_{t}^{H}
$$

where,

$$
\begin{aligned}
& H_{t}=\sum_{s=1}^{\infty} \beta^{s} D_{t, t+s} W_{t+s} L_{t+s} \\
& R_{t}^{H}=\frac{H_{t}+W_{t} L_{t}}{H_{t-1}} \\
& V_{t}=\overrightarrow{\gamma_{t+1}(j)^{\prime}}\left(\overrightarrow{X_{t}}\right) \\
& R_{., t}=\frac{X_{., ., t}+\Pi_{., ., t}}{X_{t-1}} \quad\left(=\frac{Q_{t}}{Q_{t-1}} R_{t}^{*}\right) \\
& \bar{\gamma}_{,,, t+1}=\frac{\gamma_{.,, t+1} X_{., ., t}}{\vec{\gamma}_{t+1} \vec{X}_{., ., t}} \\
& R_{t}=\overrightarrow{\bar{\gamma}}_{t}^{\prime} \overrightarrow{R_{,, ., t}} \\
& D_{t+s, t+s+k}=\frac{U_{C}\left(C_{t+s+k}, L_{t+s+k}\right)}{U_{C}\left(C_{t+s}, L_{t+s}\right)} \text {. }
\end{aligned}
$$

denote human capital, return on human capital, financial wealth, return on equity, return on portfolio, and the stochastic discount factor.

\section{A. Linearization}

Prices can be expressed as

$$
\begin{aligned}
p_{N, t} & =w_{t}-a_{N, t} \\
p_{h, t} & =w_{t}-a_{T, t} \\
p_{f, t} & =w_{t}^{*}-a_{T, t}^{*}+q_{t} \\
p_{T, t} & =n p_{h, t}+(1-n) p_{f, t} \\
0 & =\eta p_{N, t}+(1-\eta) p_{T, t} .
\end{aligned}
$$

Optimal consumption allocation can be expressed as

$$
\begin{aligned}
c_{h, t} & =-\omega\left(p_{h, t}-p_{T, t}\right) c_{T, t} \\
c_{f, t} & =-\omega\left(p_{f, t}-p_{T, t}\right) c_{T, t} \\
c_{T, t} & =-\theta p_{T, t} c_{t} \\
c_{N, t} & =-\theta p_{N, t} c_{t} .
\end{aligned}
$$


Goods market clearing conditions can be expressed as

$$
\begin{aligned}
y_{N, t} & =a_{N, t}+l_{N, t}=c_{N, t} \\
y_{h, t} & =a_{T, t}+l_{T, t}=n c_{h, t}+(1-n) c_{h, t}^{*} .
\end{aligned}
$$

Home labor market clearing condition is

$$
l_{t}=\eta l_{N, t}+(1-\eta) l_{T, t} .
$$

Let $\psi=\frac{U_{L L}(\bar{C}, \bar{L}) \bar{L}}{U_{L}(\bar{C}, \bar{L})}, \phi_{C}=-\frac{U_{C L}(\bar{C}, \bar{L}) \bar{L}}{U_{C}(\bar{C}, \bar{L})}, \phi_{L}=\frac{U_{C L}(\bar{C}, \bar{L}) \bar{C}}{U_{L}(\bar{C}, \bar{L})}$ and $\rho=-\frac{U_{C C}(\bar{C}, \bar{L}) \bar{C}}{U_{C}(\bar{C}, \bar{L})}$. The first order condition for labor supply is

$$
w_{t}=\psi l_{t}+\phi_{C} l_{t}+\phi_{L} c_{t}+\rho c_{t}
$$

The optimal risk sharing condition implies

$$
q_{t}=\rho\left(c_{t}-c_{t}^{*}\right)+\phi_{C}\left(l_{t}-l_{t}^{*}\right)
$$

Using 14 equations (A9)-(A22) and their foreign counterparts, I can solve for 13 unknown home variables $\left\{c_{t}, w_{t}, l_{t}, c_{h, t}, c_{f, t}, c_{T, t}, c_{N, t}, l_{N, t}, l_{T, t}, p_{h, t}, p_{f, t}, p_{T, t}, p_{N, t}\right\}$, their foreign counterparts and $q_{t}$ given $a_{T, t}, a_{N, t}$ and their foreign counterparts. By Walras's Law, the foreign counter part of equation (A22) is redundant.

\section{B. Solution: World Variables}

Combining the goods market clearing condition, the world labor hours and world consumption can be solved as a function of world technology level:

$$
\begin{aligned}
l_{t}^{W} & =\frac{1-\phi_{L}-\rho}{\psi+\phi_{C}+\phi_{L}+\rho}\left[\eta a_{N, t}^{W}+(1-\eta) a_{T, t}^{W}\right] \\
c_{t}^{W} & =\frac{1+\psi+\phi_{C}}{\psi+\phi_{C}+\phi_{L}+\rho}\left[\eta a_{N, t}^{W}+(1-\eta) a_{T, t}^{W}\right] .
\end{aligned}
$$

Note that $\eta a_{N, t}^{W}+(1-\eta) a_{T, t}^{W}$ is the weighted average of world productivity level.

Combining each country's traded goods market clearing condition I get

$$
a_{T, t}^{W}+l_{T, t}^{W}=-\theta\left(w_{t}^{W}-a_{T, t}^{W}\right)+c_{t}^{W} .
$$

Using the above world traded goods market clearing conditions, I get labor hours in traded good sectors and consumption of traded goods:

$$
\begin{aligned}
& l_{T, t}^{W}=(\theta-1) \eta\left(a_{T, t}^{W}-a_{N, t}^{W}\right)+\frac{1-\phi_{L}-\rho}{\psi+\phi_{C}+\phi_{L}+\rho}\left[\eta a_{N, t}^{W}+(1-\eta) a_{T, t}^{W}\right] \\
& c_{T, t}^{W}=\theta \eta\left(a_{T, t}^{W}-a_{N, t}^{W}\right)+\frac{1+\psi+\phi_{C}}{\psi+\phi_{C}+\phi_{L}+\rho}\left[\eta a_{N, t}^{W}+(1-\eta) a_{T, t}^{W}\right] .
\end{aligned}
$$


Nontraded goods can be solved in a similar way:

$$
\begin{aligned}
& l_{N, t}^{W}=(\theta-1)(1-\eta)\left(a_{N, t}^{W}-a_{T, t}^{W}\right)+\frac{1-\phi_{L}-\rho}{\psi+\phi_{C}+\phi_{L}+\rho}\left[\eta a_{N, t}^{W}+(1-\eta) a_{T, t}^{W}\right] \\
& c_{N, t}^{W}=\theta(1-\eta)\left(a_{N, t}^{W}-a_{T, t}^{W}\right)+\frac{1+\psi+\phi_{C}}{\psi+\phi_{C}+\phi_{L}+\rho}\left[\eta a_{N, t}^{W}+(1-\eta) a_{T, t}^{W}\right] .
\end{aligned}
$$

\section{Solution: Relative Variables}

I make use of complete market condition:

$$
q_{t}=\rho c_{t}^{R}+\phi_{C} l_{t}^{R} .
$$

By taking the difference of variables, I can solve for the allocation:

$$
\begin{aligned}
c_{t}^{R} & =\frac{\kappa_{C N}}{K} \eta a_{N, t}^{R}+\frac{\kappa_{C T}}{K}(\omega-1)(1-\eta) a_{T, t}^{R} \\
l_{t}^{R} & =\frac{\kappa_{L N}}{K} \eta a_{N, t}^{R}+\frac{\kappa_{L T}}{K}(\omega-1)(1-\eta) a_{T, t}^{R},
\end{aligned}
$$

where

$$
\begin{aligned}
\kappa_{C N} & \equiv 1+\phi_{C}(1-\theta+\eta \theta)+[1+(\omega-1)(1-\eta)] \psi, \quad \kappa_{C T} \equiv-\left(\eta \psi+\phi_{C}\right), \\
\kappa_{L N} & \equiv \eta-\rho(1-\theta+\eta \theta)-[1+(\omega-1)(1-\eta)] \phi_{L}, \quad \kappa_{L T} \equiv \rho+\eta \phi_{L} \\
K & \equiv \kappa_{L T} \kappa_{C N}-\kappa_{C T} \kappa_{L N} \\
& =\rho+\eta \phi_{L}+\eta\left(\eta \psi+\phi_{C}\right)+(1-\eta)(\eta \theta+\omega)\left(\rho \psi-\phi_{C} \phi_{L}\right)
\end{aligned}
$$

Then, substituting these into equation (A29)

$$
q_{t}=\rho c_{t}^{R}+\phi_{c} l_{t}^{R}=\frac{\kappa_{Q N}}{K} \eta a_{N, t}^{R}+\frac{\kappa_{Q T}}{K}(\omega-1)(1-\eta) a_{T, t}^{R}
$$

where

$$
\begin{aligned}
& \kappa_{Q N} \equiv \rho \kappa_{C N}+\phi_{C} \kappa_{L N}=\rho+\eta \phi_{C}+[1+(\omega-1)(1-\eta)]\left(\psi \rho-\phi_{C} \phi_{L}\right) \\
& \kappa_{Q T} \equiv \rho \kappa_{C T}+\phi_{C} \kappa_{L T}=-\left(\psi \rho-\phi_{C} \phi_{L}\right) \eta
\end{aligned}
$$

For consumption of traded goods and nontraded goods:

$$
\begin{aligned}
c_{T, t}^{R} & =c_{t}^{R}-\theta q_{t} \\
& =\left(\frac{\kappa_{C N}}{K}-\theta \frac{\kappa_{Q N}}{K}\right) \eta a_{N, t}^{R}-\left(\frac{\kappa_{C T}}{K}+\theta \frac{\kappa_{Q T}}{K}\right)(1-\eta)(\omega-1) a_{T, t}^{R} \\
c_{N, t}^{R} & =\frac{1}{\eta} c_{t}^{R}-\frac{1-\eta}{\eta} c_{T, t}^{R}=c_{t}^{R}+\frac{1-\eta}{\eta} \theta q_{t}^{R} \\
& =\left(\frac{\kappa_{C N}}{K}+\frac{1-\eta}{\eta} \theta \frac{\kappa_{Q N}}{K}\right) \eta a_{N, t}^{R}+\left(\frac{\kappa_{C T}}{K}+\frac{1-\eta}{\eta} \theta \frac{\kappa_{Q T}}{K}\right)(1-\eta)(\omega-1) a_{T, t}^{R} .
\end{aligned}
$$


The relative labor hours of both sectors expressed using other endogenous variables are

$$
\begin{aligned}
& l_{T, t}^{R}=-\omega\left(\psi l_{t}^{R}+\phi_{L} c_{t}^{R}\right)+(\omega-1) a_{T, t}^{R} \\
& l_{N, t}^{R}=-\theta\left(\psi l_{t}^{R}+\phi_{C} l_{t}^{R}+\phi_{L} c_{t}^{R}+\rho c_{t}^{R}\right)+c_{t}^{R}-(1-\theta) a_{N, t}^{R} .
\end{aligned}
$$

\section{Appendix II. Supporting Portfolio}

\section{A. Returns on Assets}

So far I solved real allocation using the complete market condition. I will find a supporting portfolio for the complete market allocation. I first solve for the returns on assets and then show the supporting portfolio.

\section{Return on Human Capital}

Recall

$$
H_{t}=\sum_{s=0}^{\infty} \beta^{s+1} E_{t} D_{t, t+s+1} W_{t+s+1} L_{t+s+1}
$$

In linear form:

$$
h_{t}=\frac{1-\beta}{\beta} \sum_{s=0}^{\infty} \beta^{s+1} E_{t}\left(d_{t, t+s+1}+w_{t+s+1}+l_{t+s+1}\right)
$$

where $d_{t, t+s+1}=\rho\left(c_{t}-c_{t+s+1}\right)+\phi_{C}\left(l_{t}-l_{t+s+1}\right)$; therefore,

$$
h_{t}=\frac{1-\beta}{\beta} \sum_{s=0}^{\infty} \beta^{s+1}\left[\left(\rho c_{t}+\phi_{c} l_{t}\right)+E_{t}\left(\psi l_{t+s+1}+\phi_{L} c_{t+s+1}+l_{t+s+1}\right)\right] \text {. }
$$

Return on the Human capital is defined as follows:

$$
R_{t}^{H}=\beta \frac{H_{t}+W_{t} L_{t}}{H_{t-1}} .
$$

In linear form,

$$
\begin{aligned}
r_{t}^{H} & =\beta h_{t}+(1-\beta)\left(w_{t}+l_{t}\right)-h_{t-1} \\
& =\rho \Delta c_{t}+\phi_{c} \Delta l_{t}+(1-\beta) \sum_{s=0}^{\infty} \beta^{s} \hat{E}_{t}\left(\psi l_{t+s}+\phi_{L} c_{t+s}+l_{t+s}\right),
\end{aligned}
$$

where, $\hat{E}_{t} X_{t+s} \equiv E_{t} X_{t+s}-E_{t-1} X_{t+s}$. 


\section{Returns on Equities}

Dividend of each sector can be written

$$
\begin{aligned}
\pi_{T, h, t} & =w_{t}+l_{T, t}, \\
\pi_{T, f, t} & =q_{t}+w_{t}^{*}+l_{T, t}^{*}, \\
\pi_{N, h, t} & =w_{t}+l_{N, t} .
\end{aligned}
$$

The stock price of the home firms, for example, can be written,

$$
x_{., h, t}=\frac{1-\beta}{\beta} \sum_{s=0}^{\infty} \beta^{s+1}\left[\left(\rho c_{t}+\phi_{c} l_{t}\right)+E_{t}\left(\psi l_{t+s+1}+\phi_{L} c_{t+s+1}+l_{., t+s+1}\right)\right] .
$$

Therefore, I can write returns on equities as

$$
\begin{aligned}
& r_{., h, t}=\rho \Delta c_{t}+\phi_{c} \Delta l_{t}+(1-\beta) \sum_{s=0}^{\infty} \beta^{s} \hat{E}_{t}\left(\psi l_{t+s}+\phi_{L} c_{t+s}+l_{., t+s}\right) \\
& r_{., f, t}^{*}=\rho \Delta c_{t}^{*}+\phi_{c} \Delta l_{t}^{*}+(1-\beta) \sum_{s=0}^{\infty} \beta^{s} \hat{E}_{t}\left(\psi l_{t+s}^{*}+\phi_{L} c_{t+s}^{*}+l_{., t+s}^{*}\right) \\
& r_{., f, t}=\rho \Delta c_{t}+\phi_{c} \Delta l_{t}+(1-\beta) \sum_{s=0}^{\infty} \beta^{s} \hat{E}_{t}\left(\psi l_{t+s}^{*}+\phi_{L} c_{t+s}^{*}+l_{., t+s}^{*}\right)
\end{aligned}
$$

Note that there is no ex-ante excess returns.

\section{Solution: Portfolio Allocation}

Given the same markup rate across sectors, the share of the firms in each sector should equal the consumption weight. In addition, as the consumption basket and ex-ante value of each firm in each sector are identical between Home and Foreign, the optimal share should be symmetric. The portfolio weight of each sector must be $\eta$ and $1-\eta$. Let $\delta_{T}$ be the time invariant portfolio weight of Foreign equities in the traded good sector equities of Home household and $\delta_{N}$ be the portfolio weight of Foreign equities in the nontraded good sector. In order for equity market to clear, we need $\delta^{*}=\frac{n}{1-n} \delta$. I will find this class of portfolio which satisfies the budget constraint with complete market allocation. Then, this portfolio supports complete market allocation.

First, portfolio returns of Home and Foreign household are

$$
\begin{aligned}
& r_{t}=(1-\eta)\left[\left(1-\delta_{T}\right) r_{T, h, t}+\delta_{T} r_{T, f, t}\right]+\eta\left[\left(1-\delta_{N}\right) r_{N, h, t}+\delta_{N} r_{N, f, t}\right] \\
& r_{t}^{*}=(1-\eta)\left[\delta_{T}^{*} r_{T, h, t}^{*}+\left(1-\delta_{T}^{*}\right) r_{T, f, t}^{*}\right]+\eta\left[\delta_{N}^{*} r_{N, h, t}^{*}+\left(1-\delta_{N}^{*}\right) r_{N, f, t}^{*}\right] .
\end{aligned}
$$

Let

$$
r_{., t}^{R} \equiv r_{., h, t}-r_{., f, t}=r_{., h, t}^{*}-r_{., f, t}^{*}
$$

be the return of Home equities in each sector relative to that of Foreign equities. 
The budget constraint can be linearized as follows:

$$
c_{t}+\frac{\beta}{1-\beta}\left[(1-\zeta) v_{t}+\zeta h_{t}\right]=\frac{1}{1-\beta}\left[(1-\zeta)\left(r_{t}+v_{t-1}\right)+\zeta\left(r_{t}^{H}+h_{t-1}\right)\right] .
$$

Then, the relative budget constraint is

$$
c_{t}^{R}+\frac{\beta}{1-\beta}\left[(1-\zeta) v_{t}^{R}+\zeta h_{t}^{R}\right]=\frac{1}{1-\beta}\left[(1-\zeta)\left(r_{t}^{R}+v_{t-1}^{R}\right)+\zeta\left(r_{t}^{H^{R}}+h_{t-1}^{R}\right)\right] .
$$

With $\delta^{*}=\frac{n}{1-n} \delta$. and the sector weight of $\eta$ and $1-\eta$, it is trivial to see that world budget constraint holds.

Note that

$$
\begin{gathered}
h_{t}^{R}=\frac{1-\beta}{\beta} \sum_{s=0}^{\infty} \beta^{s+1}\left[\left(\rho c_{t}^{R}+\phi_{c} l_{t}^{R}\right)+E_{t}\left(\psi l_{t+s+1}^{R}+\phi_{L} c_{t+s+1}^{R}+l_{t+s+1}^{R}\right)\right] \\
v_{t}^{R}=\frac{1-\beta}{\beta} \sum_{s=0}^{\infty} \beta^{s+1}\left\{\left(\rho c_{t}^{R}+\phi_{c} l_{t}^{R}\right)\right. \\
\quad+(1-\eta)\left(1-\frac{1}{1-n} \delta_{T}\right) E_{t}\left(\psi l_{t+s+1}^{R}+\phi_{L} c_{t+s+1}^{R}+l_{T, t+s+1}^{R}\right) \\
\left.+\eta\left(1-\frac{1}{1-n} \delta_{N}\right) E_{t}\left(\psi l_{t+s+1}^{R}+\phi_{L} c_{t+s+1}^{R}+l_{N, t+s+1}^{R}\right)\right\} .
\end{gathered}
$$

By substituting these and rearranging, I get

$$
\begin{aligned}
& \delta_{T}(1-\eta)(1-\omega)\left(\psi l_{t}^{R}+\phi_{L} c_{t}^{R}-a_{T, t}^{R}\right) \\
& \quad+\delta_{N} \eta\left[(1-\theta)\left(\psi l_{t}^{R}+\phi_{L} c_{t}^{R}-a_{N, t}^{R}\right)-\theta\left(\rho c_{t}^{R}+\phi_{C} l_{t}^{R}\right)+c_{t}^{R}\right] \\
= & \frac{1-n}{1-\zeta}\left(\rho c_{t}^{R}+\phi_{C} l_{t}^{R}+\psi l_{t}^{R}+\phi_{L} c_{t}^{R}+l_{t}^{R}-c_{t}^{R}\right) .
\end{aligned}
$$

Substituting $c_{t}^{R}$, and $l_{t}^{R}$ using equations (A30) and (A31), we can express the above only by $a_{N, t}^{R}$ and $a_{T, t}^{R}$. If $\omega=1$, then we cannot determine the traded good sector equities portfolio. However, if $\omega \neq 1$, then there exists the unique portfolio that satisfies the budget constraint:

$$
\begin{aligned}
& \delta_{T}=\frac{1-n}{1-\zeta}\left\{1+\frac{(1-\eta)(\theta-1) \frac{\phi_{C}}{\rho}}{\frac{\eta}{\rho}(\psi+1)+[(\theta-1)(1-\eta)-\eta]\left[1+\frac{\psi \rho-\phi_{C} \phi_{L}}{\rho}\right]}\right\} \text { if, } \omega \neq 1 \\
& \delta_{N}=\frac{1-n}{1-\zeta}\left\{1+\frac{(1-\eta)(\theta-1) \frac{\phi_{C}}{\rho}-\frac{\psi+1}{\rho}+\left[1+\frac{\psi \rho-\phi_{C} \phi_{L}}{\rho}\right]}{\frac{\eta}{\rho}(\psi+1)+[(\theta-1)(1-\eta)-\eta]\left[1+\frac{\psi \rho-\phi_{C} \phi_{L}}{\rho}\right]}\right\}
\end{aligned}
$$

with exception when denominator becomes zero. Otherwise, this portfolio supports the complete market allocation. 


\section{REFERENCES}

Backus, David K., and Gregor W. Smith, 1993, "Consumption and real exchange rates in dynamic economies with non-traded goods," Journal of International Economics, Vol. 35, No. 3-4 (November), pp. 297-316.

, Patrick J. Kehoe, and Finn E. Kydland, 1992, “International Real Business Cycles,” Journal of Political Economy, Vol. 100, No. 4 (August), pp. 745-75.

Balsam, Ayelet, and Zvi Eckstein, 2001, "Real Business Cycles in a Small Open Economy with Non-Traded Goods." unpublished manuscript, Tel Aviv University.

Baxter, Marianne, and Urban J. Jermann, 1997, "The International Diversification Puzzle Is Worse Than You Think,” American Economic Review, Vol. 87, No. 1 (March), pp. 170-80.

and Robert G. King, 1998, "Nontraded Goods, Nontraded Factors, and International Non-Diversification,” Journal of International Economics, Vol. 44, pp. 211-29.

Benigno, Ginluca, and Christoph Toenissen, 2006, "Consumption and Real Exchange Rate with Incomplete Markets and Non-traded goods," unpublished manuscript, London School of Economics and University of St Andrews, (London).

Bottazzi, Laura, Paolo Pesenti, and Eric van Wincoop, 1996, "Wages, Profits and the International Portfolio Puzzle," European Economic Review, Vol. 40, No. 2 (February), pp. 219-54.

Burstein, Ariel T., Joao C. Neves, and Sergio Rebelo, 2003, "Distribution costs and real exchange rate dynamics during exchange-rate-based-stabilizations," Journal of Monetary Economics, Vol. 50, No. 6, pp. 1189-1214.

, Martin Eichenbaum, and Sergio Rebelo, 2005, "The Importance of Nontradable Goods Prices in Cyclical Real Exchange Rate Fluctuations," Journal of Political Economy, Vol. 113, No. 4 (August), pp. 742-784. and __ 2006, "Large Devaluations and the Real Exchange Rate," Japan and the World Economy, Vol. 18, No. 3 (August), pp. 247-253.

Chari, V. V., Patrick J. Kehoe, and Ellen R. McGrattan, 2002, "Can Sticky Price Models Generate Volatile and Persistent Real Exchange Rates?," Review of Economic Studies, Vol. 69, No. 3 (July), pp. 533-63.

Cole, Harold L., and Maurice Obstfeld, 1991, "Commodity Trade and International Risksharing: How Much Do Financial Markets Matter?," Journal of Monetary Economics, Vol. 28, pp. 3-24.

Corsetti, Giancarlo, Luca Dedola, and Sylvain Leduc, 2006, "DSGE models with high exchange rate volatility and low pass-through.” unpublished manuscript, European University Institute.

Devereux, Michael B., Allan W. Gregory, and Gregor W. Smith, 1992, "Realistic Cross-Country Consumption Correlations in a Two-Country Real Business Cycle Model," Journal of International Money and Finance, Vol. 11, pp. 3-16. , and Alan Sutherland, 2006, "Solving for Country Portfolios in Open Economy Macro Models." manuscript, University of Britich Columbia and University of St Andrews. 
, and __ , 2007, "Country Portfolios Dynamics.” manuscript, University of Britich Columbia and University of St Andrews.

, and __ 2007, "Monetary Policy Rules and International Portfolio Choice.” manuscript, University of Britich Columbia and University of St Andrews.

Engel, Charles, and Akito Matsumoto, 2006, "Portfolio Choice in a Monetary Open-Economy DSGE Model." manuscript, University of Wisconsin and IMF.

, and Kenneth M. Kletzer, 1989, "Saving and Investment in an Open Economy with Non-Traded Goods," International Economic Review, Vol. 30 (November), pp. 735-52.

Evans, Martin D. D., and Viktoria Hnatkovska, 2005, "International Capital Flows, Returns and World Financial Integration.” Unpublished manuscript Georgetown Univesity.

, and __ , 2006, "Solving General Equilibrium Models with Incomplete Markets and Many Assets.” Unpublished manuscript Georgetown Univesity.

, and __ 2007, "International Financial Integration and The Real Economy," IMF Staff Paper, Vol. Annual Research Conference volume.

Ghironi, Fabio, Jaewoo Lee, and Alessandro Rebucci, 2007, “The Valuation Channel of External Adjustment." NBER Working paper.

Heathcote, Jonathan, and Fabrizio Perriy, 2004, "The international diversification puzzle is not as bad as you think," (August). Working Paper.

Hnatkovska, Viktoria, 2005, "Home Bias and High Turnover: Dynamic Portfolio Choice with Incomplete Markets.” Unpublished manuscript Georgetown Univesity.

Jermann, Urban J., 2002, "International Portfolio Diversification and Endogenous Labor Supply Choice," European Economic Review, Vol. 46, pp. 507-22.

Julliard, Christian, 2002, "The International Diversification Puzzle is not Worse Than You Think." Princeton University.

Kollmann, Robert, 2006, “A Dynamic General Equilibrium Model of International Portfolio Holdings: Comment,” Econometrica, Vol. 74, pp. 269-273.

, 2006, "International Portfolio Equilibrium and the Current Account," (October). mimeo, Free University of Brussels.

Lewis, Karen K., "Puzzles in International Financial Markets," 1995, in Gene M. Grossman, and Kenneth Rogoff, eds., Handbook of International Economics, Vol. 3 (Amsterdam: Elsvier Science B.V.), chapter 37, pp. 1913-71.

, 1996, "What Can Explain the Apparent Lack of International Consumption Risk Sharing?," Journal of Political Economy, Vol. 104, No. 2 (April), pp. 267-97.

, 1999, “Trying to Explain Home Bias in Equities and Consumption," Journal of Economic Literture, Vol. 37, No. 2 (June), pp. 571-608.

Lustig, Hanno, and Stijn Van Nieuwerburgh, 2006, “The Returns on Human Wealth: Good News on

Wall Street is Bad News on Main Street," Review of Financial Studies, forthcoming. 
Mendoza, Enrique G., 1995, "The Terms of Trade, the Real Exchange Rate, and Economic

Fluctuations," International Economic Review, Vol. 36, No. 1 (February), pp. 101-137.

Obstfeld, Maurice, and Kenneth Rogoff, 2005, "Global Current Account Imbalances and Exchange Rate Adjustments,” Brookings Papers on Economic Activity, Vol. 2005, No. 1, pp. 67-123.

, and ___ "The Unsustainable US Current Account Position Revisited," 2005, in Richard

Clarida, ed., G7 Current Account Imbalances: Sustainability and Adjustment, (Chicago: The

University of Chicago Press).

Ostry, Jonathan D., and Carmen M Reinhart, 1992, "Private Saving and Terms of Trade Shocks," IMF Staff Papers, Vol. 39, No. 3 (September), pp. 495-517.

Palacios-Huerta, Ignacio, 2001, "The Human Capital of Stockholders and the International

Diversification Puzzle," Journal of International Economics, Vol. 54, pp. 309-31.

Pesenti, Paolo, and Eric van Wincoop, 2002, "Can Nontradables Generate Substantial Home Bias?," Journal of Money, Credit, and Banking, Vol. 34, pp. 25-50.

Ruhl, J. Kim, 2005, “The Elasticity Puzzle in International Economics,” (February). mimeo, University of Texas at Austin.

Serrat, Angel, 2001, "A Dynamic Equilibrium Model of International Portfolio Holdings," Econometrica, Vol. 69, pp. 1467-1489.

Stockman, Alan C., and Harris Dellas, 1989, "International Portfolio Nondiversification and Exchange Rate Variability," Journal of International Economics, Vol. 26, pp. 271-89.

, and Linda L. Tesar, 1995, "Tastes and Technology in a Two-Country Model of the Business Cycle: Explaining International Comovements," American Economic Review, Vol. 84, No. 5, pp. 168-85.

Tesar, Linda L., 1993, "International Risk-Sharing and Nontraded Goods," Journal of International Economics, Vol. 35, pp. 69-89.

Tille, Cédric, and Eric van Wincoop, 2007, "International Capital Flows," (January). Federal Reserve Bank of New York and University of Virginia.

van Wincoop, Eric, and Francis E. Warnock, 2006, "Is Home Bias in Assets Related to Home Bias in Goods?," (November). University of Virginia. 